\title{
De los goliardos a los clérigos «falsos»*
}

\author{
From goliards to «false» clergymen
}

\author{
Ana ArRanz Guzmán**
}

\begin{abstract}
RESUMEN
Los goliardos han sido estudiados casi de manera exclusiva desde la óptica de la filología, ya que el denominador común de estos personajes fue su poesía en latín. $A$ lo largo de estas páginas, sin embargo, se

ha pretendido hacer un recorrido por aquellos aspectos más ligados a los intereses históricos. Por un lado, se examina su riqueza como subgrupo estamental, dado el interés que despiertan su particular comportamiento vital y su singular mirada sobre el modelo de sociedad en el que se desenvolvieron. Por otro, se analiza la posible relación de los protagonistas de este movimiento cultural con los denominados clérigos

vagabundos, malhechores de corona y clérigos falsos, denunciados especialmente a fines del Medievo en la

Corona de Castilla.

\section{ABSTRACT}

The Goliards have been studied almost exclusively from a literary point of view, since the common denominator that unites them was their Latin poetry. However, this study intends to cover certain aspects of historical interest. On the one hand, their wealth will be examined as they conformed a specific social class and there has been considerable interest in their collective behaviour and unique outlook on the social context they lived in. On the other hand, this study also looks at the possible relationship among the major figures of this cultural movement and those labelled vagabond clergymen, wrongdoers, and false clergymen, denounced especially at the end of the Middle Ages in the Crown of Castile.
\end{abstract}

\section{PALABRAS CLAVE}

Goliardo, poesía latina, clérigos vagabundos, clérigos falsos, Medievo, Corona de Castilla.

\section{KEY WORDS}

Goliards, Latin poetry, Vagabond clergymen, False clergymen, Middle Ages, Crown of Castile

\footnotetext{
* Fecha de recepción del artículo: 2011-12-28. Fecha de aceptación del artículo: 2012-02-18.

Este artículo se enmarca en los proyectos de investigación: HAR 2008-04696/HIST y HAR 201016762 del Ministerio de Ciencia e Innovación.

** Departamento de Historia Medieval, Universidad Complutense de Madrid. C.e.: aarranzg@ghis.ucm.es
} 


\section{INTRODUCCIÓN}

Por el mundo de los goliardos empecé a interesarme hace ya mucho tiempo, a raíz de la realización de algunos trabajos sobre las características del bajo clero, y sobre la percepción que los ciudadanos de Castilla tenían del escalafón inferior del estamento eclesiástico, de acuerdo con las noticias proporcionadas por sus cuadernos de peticiones dirigidos a las Cortes castellanas ${ }^{1}$. Llegué a él, además, de forma indirecta, un poco por casualidad, debido a la curiosidad que despertaron en mí una serie de términos recogidos en las actas de Cortes de los siglos XIV y XV, tales como los de «clérigos vagabundos», «clérigos bebedores y trasnochadores», «clérigos malhechores» o «clérigos falsos». Desde entonces quise averiguar hasta qué punto podía existir una relación entre los goliardos —clérigos escolares-y este grupo o subgrupo de eclesiásticos, sin duda el más bajo del estamento -aunque lo más probable es que no todos los denunciados en Cortes pertenecieran a él— tan abiertamente criticado por los procuradores de las ciudades. En aquellos momentos tenía, sin embargo, otras líneas de investigación marcadas por lo que, finalmente, decidí postergar su estudio. El tema, aunque conscientemente arrinconado durante todos estos años a pesar de no dejar de recopilar información sobre él, me pareció siempre fascinante, y más por el hecho de que los estudiosos del goliardismo procedieran mayoritariamente del campo de la filología clásica, si dejamos al margen las pinceladas ofrecidas por ciertos medievalistas en trabajos de carácter general sobre el Medievo o la cultura medieval². Es lógico, por otra parte, que la investigación sobre los goliardos haya sido un monopolio de los filólogos, ya que si buscamos un denominador común entre estos personajes es, en buena medida, su poesía en latín ${ }^{3}$. Otra cosa es la enorme complejidad que entrañan los miembros de

1 Cf. A. ARRANZ GUZMÁN, «La cultura en el bajo clero: una primera aproximación», Anuario de Estudios Medievales, 1991, págs. 591-605, y «Clérigos y laicos en las Cortes castellano-leonesas: la conflictividad como hilo conductor», en El Reino de León en la Alta Edad Media, IX, León, 1997, págs. 637-717.

2 Tal es el caso, por ejemplo, de J. Le GOFF en su obra Los intelectuales en la Edad Media, Barcelona, 1999, págs. 39-43.

${ }^{3}$ Los estudios sobre los goliardos y su poesía son abundantes desde el campo de la filología, así como las traducciones y análisis de sus poemas y de las colecciones poéticas más famosas conservadas, por lo que me limitaré a mencionar sólo algunos de los que guardan mayor relación con el presente trabajo y que además proporcionan una abundante bibliografía especializada sobre la poesía latina en el Medievo: J. A. SCHMELLER, Carmina Burana, Sttutgart, 1847; K. STRECKER, Carmina Cantabrigensia, Berlín, 1926; O. DOBIACHE-ROJDESVENSKY, Les poésies des goliards, París, 1931; R. ARIAS Y ARIAS, La poesía de los goliardos, Madrid, 1970; R. GARCÍA VILLOSLADA, La poesía rítmica de los goliardos medievales, Madrid, 1975; C. YARZA Y L. MOLES, Cantos de goliardo, Barcelona, 1978; E. MASSA, Carmina Burana e altri canti della goliardia medievale, Roma, 1979; L. A. DE VILLENA, Dados, amor y clérigos. El mundo de los goliardos en la Edad Media europea, Madrid, 1978; G. CAVALLO, C. LEONARDI Y E. MENESTÒ (dirs.) Lo Spazio Letterario del Medievo, Roma, 1993-1998; M. A. MARCOS CASQUERO, «El mundo de los goliardos y clérigos vagabundos», Estudios Humanísticos de Filología, 19 (1997), págs.. 67-89. E. MONTERO CARTELLE, Carmina Burana. Los poemas de amor, Madrid, 2001; E. WOLFF, Le Chansonnier amoureux. Carmina Riuipullensia, Mónaco, 2001; M. REQUENA, Poesía goliárdica, Barcelona, 2003; J. A. ESTÉVEZ SOLA, Carmina Burana. Antología, Madrid, 2006; T. JIMÉNEZ CALVENTE, Sátira, Amor y Humor en la Edad Media Latina: cincuenta y cinco canciones de Goliardos, Madrid, 2009. 
este movimiento cultural, motivo por el que quizá los latinistas tampoco hayan llegado a un total acuerdo a la hora de establecer una única definición sobre ellos.

En estas páginas, lejos de volver a insistir en los temas de carácter propiamente filológico, he centrado mi atención en aquellos de especial interés historiográfico: las características socio-culturales de los goliardos, sus diferentes comportamientos; la visión que tuvieron de la sociedad que les tocó vivir; el rechazo progresivo que inspiraron sus personas; o lo que quedó finalmente de su manera de entender la vida. Sin embargo, como se podrá ir comprobando, las fuentes con las que se cuenta para intentar reconstruir su vida y su forma de pensar y de actuar son escasas, teniendo que intuirlas, más que otra cosa, a través de sus versos. Las legislaciones eclesiástica y civil, por su parte, no ayudan demasiado en este sentido, ya que sólo proporcionan determinadas informaciones sobre los asuntos más espinosos relacionados con ellos, proyectando un perfil intencionadamente despectivo y, además, para una época tardía. El predominio del anonimato entre sus filas, finalmente, dificulta la posibilidad de obtener algo más que una imagen velada de su auténtica realidad.

\section{CATÓLICOS, INTELECTUALES Y VIVIDORES}

En el siglo XII las estructuras de la feudalidad, entendidas en el sentido más clásico, empezaron a desmoronarse. El desarrollo de las ciudades y del comercio, así como el incremento demográfico y el cada vez mayor auge de la burguesía anunciaban si no el nacimiento de una época distinta sí el florecimiento de unas realidades diferentes a las de la etapa anterior. Europa se renovó, se abrió para recibir las grandezas del mundo clásico y para plantearse objetivos mucho más amplios que los barajados hasta entonces ${ }^{4}$. Fue en ese tiempo, y fruto de la gran movilidad de esta centuria, cuando los goliardos hicieron su aparición, representando, quizá, la primera ruptura evidente con el orden social establecido. Porque estos personajes surgieron y se desenvolvieron en el mundo de la marginalidad. Los goliardos eran clerici vagantes, escolares que tenían órdenes menores o, al menos, la tonsura, lo que les permitía disfrutar del privilegium fori y, aunque no siempre y a veces excesivamente pequeño, de algún beneficio; que iban de escuela en escuela y, luego, de universidad en universidad, en busca de los más renombrados profesores y de los diferentes conocimientos que, en un momento determinado de su vida, deseaban aprender. Eran hombres cultos, pero tremendamente vitalistas, por lo que compaginaban los estudios, con una vida alegre escandalosa o disoluta según la mayoría de sus coetáneos- en donde la taberna, las canciones, el vino, el juego y las mujeres ocupaban un destacado lugar. El cisterciense Helinando (1160-1230), probablemente goliardo en su juventud antes de profesar como monje en el monasterio de Froidmond, nos dejó una descripción de

4 Una visión global sobre los cambios experimentados en la Europa de esta época la proporciona la obra ya clásica de H. HEER, El mundo medieval. Europa 1100-1350, Madrid, 1960. 
estos clerici-scholares, que iban de ciudad en ciudad, buscando en París las artes liberales, los autores clásicos en Orleans, los códices de Derecho en Bolonia, las redomas de medicina en Salerno, la nigromancia en Toledo, pero sin ocuparse jamás por aprender o desarrollar las buenas costumbres: «Urbes et orbem circumire solent scholasti, ut ex multis litteris efficiantur insani...Ecce quaerunt clerici Parisius artes liberales, Aurelianis auctores, Bononiae codices, Salerni pyxides, Toleti daemones et nusquam mores "5; y quienes, como se señala en el mismo texto, con tanta acumulación de letras y saberes acababan por volverse locos.

Lo cierto es que los goliardos representaron una forma de vivir rupturista con lo habitual, con lo cotidiano de aquellos tiempos, que consistía en componer canciones en latín, críticas o eróticas, cantarlas, frecuentar tabernas y burdeles, beber hasta emborracharse, disfrutar con el amor carnal y jugarse a los dados cuanto tenían, sin tener reparos en pedir limosna si lo precisaban; y todo ello en cada una de las ciudades por las que pasaban, en esa búsqueda de maestros y conocimientos. Unían el ardor y la rebeldía de la juventud con el interés intelectual. Pero la frescura y la crítica social de sus poemas no deben llevar a engaño, ya que estos hombres eran creyentes, católicos, aunque atacaran en sus versos a los sacerdotes de vida disoluta y a la propia jerarquía eclesiástica. Así, mientras que en muchos de sus versos arremetieron contra la avaricia de los prelados o el concubinato de los presbíteros, en otros no dudaron en dolerse del rumbo elegido por las gentes de su época, faltas de virtudes, sepultadas en el vicio y alejadas de Cristo. Los versos atribuidos a Walter Mapp representan uno de los múltiples ejemplos conservados que ilustran la crítica abierta señalada:

«iOh sacerdote!, a esto contesta,/ tú que, a menudo y de fiesta,/ con una esposa te acuestas,/ y después, de mañana, misa dices,/ el cuerpo de Cristo bendices,/ tras abrazar a una buscona,/ no tanto como tú, pecadora.» Los siguientes versos anónimos, pertenecientes al De Mundi miseria hacen lo propio respecto a la calidad de creyentes de los goliardos: «Ya el mundo se muere en el vicio sepultado,/ el orden se invierte, el culto a Cristo ha cesado;/ se exilia la justicia, el listo en tonto se ha tornado;/ en toda la provincia un tumulto se ha levantado./ (...) Cuando en la muerte pienso, me entristezco y lloro:/ una cosa es que voy a morir, pero el momento ignoro;/ lo tercero es que no sé a quién pertenecerá mi coro,/ pero que merezca unirme al suyo a Dios imploro ${ }^{6}$.

5 Cfr. MIGNE, Patrología Latina, 212, pág. 603.

6 Resulta casi un tópico decir que la traducción perfecta no existe, sobre todo cuando se trata de poesía, y más aún si es poesía en latín. Traducir manteniendo el ritmo y la rima, así como la fidelidad semántica es algo prácticamente imposible. No obstante, aunque he intercalado algunos versos en latín, he preferido en la mayoría de los casos, en especial cuando el poema era largo, y dado el propósito de este trabajo, poner la versión castellana. Las traducciones existentes sobre los poemas de los goliardos son varias, algunas muy recientes, y lo cierto es que varían mucho entre sí, hasta el extremo de que determinados versos no llegan a reconocerse de una versión a otra. No me he decidido por ningún autor concreto a la hora de seleccionar los poemas que se incluyen en estas páginas, entre otras cosas, además de lo ya apuntado, porque cada uno de ellos ya ha seleccionado o una fuente, o un autor, o un tema determinado de estudio. Así en cada nota correspondiente señalaré, siempre que no sea la versión latina, el traductor del mismo. En esta ocasión he elegido la traducción realizada por T. JIMÉNEZ CALVENTE, ob. Cit., págs. 44,46 y 47 . 
No obstante, los goliardos, a pesar de atacar la estructura social vigente, lo hacían no por ser portadores de una ideología revolucionaria, sino por considerarse los más capaces e intelectuales. Una realidad que no les había conducido a ocupar los puestos más relevantes de la sociedad; algo que no lograban entender, ni soportar. Así, ni han de ser considerados anticristianos, ni miembros de una secta o «familia Goliae», por mucho que en sus canciones jueguen con estos términos. Tampoco se les debe tener por revolucionarios, ya que, si bien no se encontraban en los peldaños del poder, no dejaban de soñar, y a veces lo lograban, con protectores o mecenas que a cambio de sus versos les garantizaran una vida holgada. El goliardismo careció de utopías, de ideología revolucionaria. Sus miembros no teorizaron sobre la creación de un nuevo orden social diferente al conocido. No eran moralistas, ni políticos, por lo que nunca hicieron profesión de fe o apoyaron alguna facción concreta, como la de los gibelinos oponentes al Papa, aunque no dudaban en versificar de forma hiriente contra los miembros de la curia romana si la ocasión lo requería. Lo único que deseaban era pasar sus días lo mejor posible, aprendiendo en las escuelas y en los caminos y dando rienda suelta al mismo tiempo a sus pasiones carnales. Tampoco tuvieron un fundador, o un jefe, aunque sí algunos modelos, como Abelardo, ni tampoco normas o reglamentos. No obstante, el mundo de los goliardos es complejo y hoy se nos sigue presentando lleno de sombras.

Pero ¿quiénes eran los goliardos? El primer problema que se plantea a la hora de profundizar en este movimiento cultural es el anonimato casi total de la producción goliárdica, lo cual no deja de ser lógico si se repara en el contenido de los poemas, excesivamente audaz en todos sus temas y en buena parte de las ocasiones. Esta realidad impide conocer, en la mayoría de los casos, tanto sus orígenes sociales como el desarrollo y final de sus carreras eclesiásticas o culturales, entre otras muchas cosas, a la vez que ha dificultado a los estudiosos llegar a un acuerdo para definir con exactitud lo que ha de entenderse por goliardo. Se puede considerar, por ejemplo, que el goliardismo fue sencillamente una actitud ante la vida; y que el verdadero goliardo ligaba su especial forma de versificar con una postura de rebelión intelectual contra lo que consideraba injusto en las instituciones establecidas, y también de rebelión vital, abrazándose siempre a todo aquello que le procuraba placer. Sin embargo, no todos los autores están de acuerdo. Así, R. García Villoslada apuntó que le parecía excesivamente restringido calificar al goliardo medieval sólo como un poeta latino popular, una especie de bohemio avant la lettre. Ya que la imagen que se obtendría sería muy limitada: la de unos clerici vagantes, de vida disoluta, que en sus poemas en latín cantaban al erotismo y a la taberna, o censuraban y se burlaban de la sociedad. Añade este autor que si uno se ciñe a esta definición, lo cierto es que «en toda la historia literaria del Medievo latino no habría más que unos poquitos goliardos de nombre conocido o de apelativo famoso: el Primate de Orleans, el Archipoeta de Colonia y pocos más», y que «hubo muchísimos poetas goliárdicos que nada tenían de vagos y errabundos, ni de disolutos en sus cos- 
tumbres " 7 . De acuerdo con su argumentación, hubo poetas que cantaron a la manera goliárdica, pero sin llevar una vida aventurera, ni juglaresca, llegando incluso a ocupar elevados puestos en la jerarquía eclesiástica, en las cortes de los reyes, o en las escuelas y universidades más célebres. En definitiva, para este autor, quien también subrayó el hecho de que los goliardos hablaron de los mismos temas que otros poetas anteriores y posteriores (fugacidad de la vida, la mujer, la primavera...), su característica esencial fue la utilización del latín y su modo de versificar: «por la naturaleza de su verso: rítmico y acentual o silábico, propio de las lenguas vernáculas, en contraposición al verso clásico de pies cuantitativos». Pero, según ya ha sido apuntado, no todos los estudiosos del tema son de la misma opinión. Algunos, por ejemplo, dan una importancia especial a la forma de vivir del poeta, alegre y en la marginalidad, por lo menos durante algún tiempo, o al deseo de haberlo hecho, por lo que han preferido distribuirles en al menos tres categorías ${ }^{8}$. Otros consideran que el investigador que intente ordenar y clasificar los poemas goliárdicos tropezará siempre con el hecho de que, a pesar de compartir los mismos temas, practicaban dos técnicas formales distintas - la métrica y la rítmica- por lo que, al final, parece obligado que las clasificaciones tengan que basarse necesariamente sólo en el contenido ${ }^{\text {. }}$ Sin entrar en valoraciones de momento, sí considero oportuno decir unas palabras sobre dos de las características fundamentales de sus poemas: la utilización del latín y su forma de versificar.

El latín medieval ha sido definido como una lengua de tradición cultural. En el siglo XII el pueblo ya se expresaba desde hacía tiempo en su lengua vernácula, pero los clérigos, los escolares de todos los países del Occidente cristiano escribían en latín y, ocasionalmente, cuando lo precisaban, también lo hablaban, facilitándose con ello la posibilidad de ir de escuela en escuela y, más adelante, de universidad en universidad, por toda Europa. Gracias a ello el latín siguió siendo en cierta medida una lengua viva, practicada por una comunidad internacional como era la formada por los clérigos y escolares; una lengua, por tanto, capaz de crear nuevos términos y construcciones sintácticas, de dar significados diferentes a expresiones antiguas, y de ser permeable a las lenguas romances. Se trataba, pues, de una lengua dúctil, empleada para la prosa escolástica y también por los poetas goliárdicos, que se mantuvo vigente hasta mediados del siglo XIV con la irrupción del latín de los humanistas. Éstos se mostraron desde el principio contrarios a las innovaciones surgidas a lo largo del Medievo; aquéllas que, sin embargo, habían hecho posible que el latín permaneciera vigente, al menos, dentro del estamento clerical. Para los humanistas, en cambio, la perfección se hallaba en la imitación de los clásicos. Este fue su camino y, al seguirlo, el latín dejó de ser definitivamente una lengua viva. Pero fue en ese latín medieval menospreciado en el que se expresaron los goliardos

7 La poesía rítmica de los goliardos, Madrid, 1975, págs. 7-8.

8 Como en el caso de L. A. DE VILLENA, Dados, amor y clérigos, Madrid, 1978. 
en sus poemas o, mejor dicho, en sus canciones, ya que sus versos estaban destinados a ser cantados ${ }^{10}$.

Lejos también de lo que harían los humanistas, los goliardos se distanciaron de la poesía clásica latina para utilizar una métrica nueva, aunque aquélla tampoco dejó de usarse en otros ámbitos culturales. Se trataba del verso rítmico, acentual, que sustituyó a la métrica cuantitativa clásica; una métrica rítmica, próxima a la empleada en las lenguas vernáculas europeas. Existe, asimismo, cierta controversia en torno a si la poesía rítmica fue o no la principal característica del goliardismo. Lo cierto es que hubo otros poetas, anteriores y posteriores a este movimiento, autores de himnos religiosos o ascéticos que la practicaron, pero que por su temática y por su manera de vivir no tuvieron nada que ver con los goliardos. En cualquier caso, su empleo no fue algo exclusivo del goliardismo. Por otra parte, la adopción de este tipo de métrica para sus canciones se explica por el hecho de que la propia evolución del latín había llegado a borrar, salvo entre los más cultos, la diferencia cuantitativa de las sílabas, base de la métrica clásica. A este tipo de métrica unieron también el uso de la rima y el cómputo de sílabas como en las lenguas romances. Por último, respecto al verso elegido por los goliardos, el más común fue el de trece sílabas o triscaidecasílabo, con la censura tras un primer hemistiquio de siete sílabas, y agrupados en estrofas de cuatro versos monorrimos.

Los problemas no terminan con la cuestión del casi generalizado anonimato de nuestros poetas, o con la definición de «goliardo» y su alcance, ya que también las teorías en torno a la propia etimología de este término son muchas. Algunos estudiosos, tomando como prueba una carta de San Bernardo de Claraval al Papa Inocencio II, en la que se refiere a su adversario Pedro Abelardo diciendo «Avanza Goliat con su descomunal cuerpo...y a mí, al más pequeño de todos me reta a singular combate ${ }^{11}$ hacen derivar el término goliardo del bíblico gigante Goliat. Un Goliat, a quien desde San Agustín y Beda, se identificó con un hombre vanidoso y soberbio, incluso como representación del diablo; y de hombre vanidoso y soberbio calificó San Bernardo a Pedro Abelardo. Pero lo más curioso es que los propios poetas llevaron a gala esos defectos señalados por el monje cisterciense.

Otra posibilidad etimológica la proporciona un poeta y juglar del palacio del arzobispo Eberhard de Salzburgo, Surianus, que señaló como fundador de los goliardos a un tal Golias «prelado y archiprimate de los escolares vagantes». Hacia 1220 Giraldo de Cambrai se refirió también a este personaje: «hubo un parásito de nombre Golias, famosísimo por su gula y su glotonería que muy bien podría llamarse Gulias, entregado como estaba a la gula y a la crápula en todo momento, pese a ser bastante buen literato...Éste a menudo y en abundancia, vomitó contra el Papa y la curia romana poesías que alcanzaron fama, tanto métricas como rít-

\footnotetext{
9 J. L. MORALEJO, en su edición de El Cancionero de Ripoll, Barcelona, 1986, p. 75.

10 Sobre la unión de la música y la poesía, véase: A. ROSELL MAYO, «Música y poesía en la lírica medieval», en V. VALCÁRCEL MARTÍNEZ y C. PÉREZ GONZÁLEZ (eds.) Poesía Medieval (Historia literaria y transmisión de textos), Burgos, 2005.
} 
micas, con no menos impudencia que imprudencia» ${ }^{12}$, emparentando los términos de Golías, goliardo y gula. No obstante, todo hace pensar que jamás existió un personaje concreto llamado Golias; que se trata de pura fabulación, puesto que otros Golias malvados aparecen en la literatura desde el siglo IX. Además, el poema que Giraldo de Cambrai atribuye al tal Golias, la «confessio Golias» —poema 191 de los Carmina Burana - en manuscritos ingleses se señala al Archipoeta de Colonia como su autor. En cualquier caso, las dudas sobre la etimología de «goliardus» se siguen manteniendo. Así, también se hace derivar el término de «gualier» (engañar) o del verbo «galam» (cantar), cuyo pretérito es «gol» ${ }^{13}$. Pero lo fundamental es que en el siglo XIII el término «goliardus» estaba ya plenamente acuñado, y que se identificaba con estudiantes pobres que cantaban poemas tabernarios o injuriosos por París, como lo demuestra el que en 1229 un cronista inglés hablara de ellos y de sus canciones ofensivas destinadas a Blanca de Castilla y al legado pontificio, «vel illos quos solemus goliardenses appellare»; y, más todavía, que desde esta centuria, la Iglesia utilizara este término de manera peyorativa, como se puede apreciar en diversos cánones conciliares, de los que luego se tratará, a la vez que de otros con los que identificaba una forma de vida poco edificante, tales como: blasfemos, maldicientes, truhanes, giróvagos, estudiantes vagabundos y «eberhardini »14. En el mismo sentido, algunos personajes pertenecientes a la jerarquía eclesiástica tampoco dudaron en criticar su forma de vida, acusando a los goliardos de ser seres depravados, gandules, borrachos y glotones, aludiendo tanto a sus excesos, incluso en la vejez, como al daño social que ocasionaban sus poemas ${ }^{15}$.

Otro asunto que ha llamado la atención y que, asimismo, ha creado confusión es el contenido del poema 219 de los Carmina Burana, al simular ser la carta fundacional de la secta goliárdica y en donde se exponen los principios de la misma:

«Nuestra secta acoge/ a justos y a injustos/ a cojos y a débiles/ a los quemados por la vejez/ a los belicosos, a los pacíicos,/ apacibles y furiosos,/ los de Bohemia, los teutónicos,/ esclavos y romanos/ a los de estatura media,/ gigantes y enanos/ a las personas humildes/ a los embusteros... Os expondré las leyes de la Orden de los vagabundos, cuya vida es noble y dulce por naturaleza, que gustan más de un abundante asado que de una sobria medida de cebada...Con razón nuestra Orden se llama secta, pues la gente que la sigue es de muy diversa procedencia.... ${ }^{16}$

Es cierto que ellos mismos, y desde fuera, se incluían en una especie de «ordo scholarium», o secta, o «familia Goliae». Pero la mayoría de los estudiosos

\footnotetext{
11 «Procedit Golias procero corpe...me omnium minumum expedit ad singulare certamen», $\mathrm{Pa}$ trología Latina, 182, 355.

12 Cf. M. A. MARCOS CASQUERO, ob. Cit. págs. 69-70.

13 Sobre el tema véase H. SPITZMULLER, Poésie latine chrétienne du Moyen Âge, Brujas, 1971.

14 Eberhardinos es el término popular con el que se denominaba a los clérigos vagabundos, según quedó recogido en las disposiciones de los concilios de 1261 y 1310 celebrados en Maguncia, Cf. J. D. MANSI, Sacrorum conciliorum nova et amplissima collectio, Florencia, 1759 y ss. XXV, pág. 311.

15 Sirva como ejemplo el poema «De certamine mundi» del obispo Raimundo de Rocossel, donde se califica al goliardo de holgazán, borracho y compositor de poemas nocivos para las personas, Cit. C. YARZA Y L. MOLES, Cantos de goliardo, Barcelona, 1978, pág. 9.
} 
coinciden en que este poema debe ser interpretado en su sentido satírico, metafórico, lleno de humor. Porque los goliardos nunca fueron un movimiento organizado, ni una entidad corporativa. Y esto es algo que les diferencia también de las múltiples fraternidades religiosas que se desarrollaron en Europa desde la plenitud medieval como consecuencia de las corrientes místicas o reformadoras surgidas en esas centurias. Todo el poema es una alusión burlesca, que emplea tales términos en sentido hiperbólico para abrazar en un único grupo a todos los que se encontraran al margen de las estructuras sociales vigentes y anhelaran vivir en libertad y que hoy, sin duda, sería calificado de «políticamente incorrecto».

Un último aspecto merecedor de atención, en cuanto que también ha creado cierta confusión, es la condición eclesiástica del goliardo; el ser clérigo, aunque un «clericus vagans». De todos es sabido cómo el término clérigo tenía varias acepciones, siendo una de ellas la de «scholaris». Con la desaparición de las escuelas paganas del Imperio romano, la Iglesia asumió la enseñanza, apareciendo los «clerici scholares», los «clerici sive scholares», que asistían a las escuelas monásticas y catedralicias. Unos aspiraban a ser sacerdotes, pero otros simplemente querían formarse para alcanzar una situación mejor en la vida, siendo conscientes de que sólo lo lograrían en los centros religiosos ${ }^{17}$. La realidad, además, era que el alumno que acudía a ellas entraba a formar parte de un organismo eclesiástico sujeto a la jurisdicción de la Iglesia, y que en esta época tanto los maestros, como los abogados o los estudiantes eran calificados de «clerici». Por ello adoptaban la tonsura como señal distintiva de pertenencia al «ordo clericalis», aunque un porcentaje indeterminado no llegara nunca a recibir ni órdenes menores, ni sagradas; algo fácil de entender, además, si se piensa en la casi segura falta vocacional de muchos de los tonsurados. Tampoco ha de olvidarse que en no pocos casos eran los padres quienes llevaban a tonsurar a sus hijos. Valga como ejemplo el que en 1397, en Ruán, en la fiesta de Pentecostés fueran tonsurados 737 niños ${ }^{18}$. Es cierto que los simples tonsurados carecían de carisma y no participaban de la «potestas ordinis», a diferencia de aquellos que recibían las órdenes, pero al ser tonsurados y pertenecer a una institución eclesial gozaban, en cuanto escolares, de muchos privilegios eclesiásticos. Por un lado, el «privilegium fori» les eximía de los tribunales civiles, por otro, el «privilegium canonis» conducía a la excomunión a todos aquellos que les provocaran algún daño físico o presión de cualquier tipo. A ello ha de unirse la exención del servicio militar y de impuestos que disfrutaban.

\footnotetext{
16 Son muchísimas las traducciones existentes de este famoso poema, valga como ejemplo la proporcionada por P. PASCUAL en su estudio Goliardos y goliardismo, Madrid, 1988, págs. 114-117.

17 G. PARÉ, A. BRUNET Y P. TREMBLAY, La résistance du XIle. siècle. Les écoles et l'enseignement, París, 1993, pág. 64.

18 R. GÉNESTAL, Le «privilegium fori» en France, du Décret de Gratian à la fin du XIV siècle, París, 1921, vol. 1, pág. 42. Para una visión global y bien estructurada de las relaciones Iglesia-Cultura en la plenitud medieval, véase: J. PAUL, La Iglesia y la cultura en Occidente (siglos IX-XII), 2 vols. Barcelona, 1988.
} 


\section{ALGUNOS POETAS GOLIARDOS: LOS PUROS, LOS INDECISOS, LOS «NOSTÁLGICOS»}

Una de las características, ya mencionada, que ha impedido profundizar en determinados aspectos de este movimiento cultural y vital es el anonimato tan generalizado que existió. La mayor parte de los poemas goliárdicos son de autor desconocido. Esta realidad, unida a los escasos datos biográficos que se conservan sobre sus componentes conocidos, invita a clasificarlos en varios grupos o categorías. El primero sería el compuesto por los que podemos denominar goliardos puros o genuinos, integrado por estudiantes y/o maestros vagabundos que fusionaron a la perfección su amor por la cultura, la juerga y la mendicidad; que buscaban la aventura, frecuentaban las tabernas y los burdeles; que cantaban sus amores carnales y al vino, a la vez que hacían sátiras contra la jerarquía eclesiástica y cualquier poder establecido. Eran los que se jugaban en una noche todo lo ganado unas horas antes, acabando muchos de ellos sus días enfermos en cualquier hospital público, unos arrepentidos de su pasado, otros no, pero todos en la más absoluta pobreza. A este grupo pertenecerían, por ejemplo, Hugo de Orleans y el Archipoeta de Colonia. Un segundo grupo estaría formado por aquellos religiosos con aficiones goliardescas que, o bien tuvieron una vida amorosa o vagabunda antes de entrar en el claustro y decidirse a versificar sobre sus recuerdos de juventud, como parece ser que hizo el llamado Enamorado de Ripoll, o bien en un momento determinado de su existencia abandonaron el monasterio para llevar una vida errante. Un tercer grupo lo integrarían los poetas que versificaron como goliardos y que tocaron los mismos temas y de igual manera. Poetas que en lo más interno de su ser admiraban, quizá incluso envidiaban, la forma de vivir del goliardo genuino, pero que jamás osaron lanzarse a los caminos, a la aventura, como Gualterio de Châtillon. Por último, cabe también mencionar a algunos personajes, tardíos en su cronología, y que no pueden ser calificados de verdaderos goliardos, entre otros motivos, por versificar ya en romance y ser sólo imitadores de las anteriores composiciones goliárdicas, pero que en sus versos mantuvieron vivo el espíritu y el sentir de los goliardos y compararon situaciones de su presente con los relatos de sus, sin duda, admirados poetas. La imitación llevada a cabo por el Arcipreste de Hita en su «Cantiga de los clérigos de Talavera» de la célebre Consultatio sacerdotum es buen reflejo de ello ${ }^{19}$. Se trata de intelectuales, quizás nostálgicos de ese pasado poético reciente o, sencillamente, críticos con unas estructuras sociales de idénticas hechuras a las vividas por los goliardos, pero, en todo caso, siempre pertenecientes al mundo de la cultura. Nada, pues, que ver con ese otro grupo, también tardío, del que se tratará más adelante, compuesto únicamente por clérigos vividores.

A pesar de que no todos los investigadores consideran acertado incluir entre los goliardos a Pedro Abelardo (1079-1142), su ajetreada vida, su posible produc-

${ }^{19}$ Libro de buen amor, edición preparada por N. SALVADOR MIGUEL, Madrid, 1972, págs. 324-327. 
ción poética y su propia confesión recogida en su Historia calamitatum mearum (1136) aconsejan lo contrario. Para unos, se trata de una figura paradigmática por su condición de intelectual, polemista, amante y goliardo en su juventud; un hombre entregado con la misma pasión a la cultura y al amor. Para otros, en cambio, nunca fue goliardo. Éstos se apoyan en la inexistencia de datos científicamente comprobados que avalen su producción poética, calificando de osados a quienes se han atrevido a afirmar que en algunos poemas de los «Carmina Burana» se intuye su aroma poético, o a quienes defienden que escribió versos a Eloísa que no tardaron en recitarse por gran parte de Europa $^{20}$. De lo que no hay duda es de que Abelardo fue modelo de un estilo de vida goliárdica, tanto por su experiencia amorosa con Eloísa como por su peregrinar de ciudad en ciudad, o por sus enfrentamientos con varios miembros de la jerarquía eclesiástica. La producción bibliográfica sobre la vida y obra de Abelardo es ingente, por lo que me limitaré a dar unas breves pinceladas sobre este complejo y atractivo personaje que levantó pasiones encontradas en su época y también en la nuestra ${ }^{21}$.

Pedro Abelardo, nacido cerca de Nantes, no quiso seguir el camino de las armas, marcado por su padre, señor de Le Pallet. Estudió con Guillermo de Champeaux, con quien acabó por enfrentarse. Con sólo veintidós años abrió su propia escuela en Melun. Su atractivo personal, su capacidad dialéctica y también su arrogancia contribuyeron a hacerle famoso muy pronto. Enseñó en Corbeil, después en París, en la montaña de Santa Genoveva. Abelardo era, por encima de todo, un lógico, por lo que se irritaba al observar cómo los teólogos eran considerados superiores desde el punto de vista intelectual. Decidió, entonces, ir a estudiar esta materia con el teólogo más reputado de su tiempo, Anselmo de Laón, aunque también acabaría enfrentándose con él. La imagen que dejó del anciano maestro en su autobiografía, ya citada, es posiblemente una de las más desoladoras a las que pueda enfrentarse un profesor reputado. De él dijo que «por el palabrerío era admirable; por la inteligencia, despreciable». En la percepción, cruel o soberbia, de Abelardo, Anselmo podía contentar a un alumno dócil, pero jamás complacer a un discípulo con verdaderas inquietudes intelectuales que no dejaba de preguntar e inquirir $^{22}$. En 1113 regresó a París, momento en el que conoció a Eloísa, sobrina del canónigo Fulberto. Se trataba de una joven bella e inteligente, de quien en seguida se enamoró. La historia es de todos conocida. Fulberto, ante la evidencia del amor nacido entre ambos, mandó castrar a Abelardo para lavar su honor. El desafortunado se retiró a la abadía de Saint Denis y Eloísa profesó como monja en el

\footnotetext{
20 Véase al respecto el trabajo de P. PASCUAL, Goliardos y goliardismo, Madrid, 1988, pág. 36.

21 La diversidad de estudios sobre Abelardo va desde el clásico de E. GILSON, Héloise et Abélard,

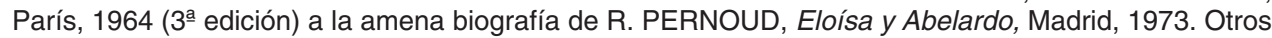
trabajos más ceñidos a asuntos puntuales son: D. E. LUSCOMBE, The School of Peter Abelard: the influence of Abbelard's Though in the Early Scholastic Period, Cambridge, 1969; A. CROCCO, Abelardo: l'altro versante del medioevo, Nápoles, 1979; J. VERGER y J. JOLIVET, Bernard-Abélard, ou le cloître et l'école, París, 1982; H. SANTIAGO-OTERO, Pedro Abelardo y la «licentia docendi», Madrid, 1984; M. FUMAGALLI y B. BROCCHIERI, Eloísa e Abelardo, Milán, 1984.

22 L. A. de VILLENA, Ob. Cit. pág. 43.
} 
monasterio de Argenteuil. Entre este año y 1118 Abelardo, a ruegos de sus discípulos volvió a impartir clases, apareciendo ya como el maestro indiscutible de la escuela de París. Es en esta etapa cuando, según algunos autores, habría despertado su espíritu goliardesco: es un lógico brillante, vive y se mezcla con los estudiantes, frecuenta las tabernas. Si escribió poemas al estilo de los goliardos tuvo que ser en esos momentos, cuando encarnaba al goliardo perfecto, cuando combinaba los estudios de lógica, el espíritu crítico, la poesía de Ovidio y la pasión por la vida. Después decidió vagar durante algún tiempo de monasterio en monasterio hasta fundar el convento del Paráclito en Nogent-sur-Seine. A partir de 1121 comenzarían a aparecer sus más famosas obras, como el Sic et Non, su Dialéctica, y su Historia calamitatum meorum. Su defensa de que la moralidad se halla más en la intención que en el acto, bueno o malo según la intención encaja perfectamente en la línea de pensamiento y conducta goliardescos. La oposición a sus teorías, así como las envidias suscitadas por su fama hicieron que voces de encumbrados pensadores se alzaran contra él. Saint-Thierry y, en especial, San Bernardo fueron dos de sus más serios oponentes. Este último, incluso, le llegó a apodar Golías. Su condena oficial se llevó a cabo en el concilio de Sens en 1140. Moriría dos años después, ya reconciliado con Roma gracias a la intervención del abad de Cluny Pedro el Venerable. En cualquier caso y al margen de que Abelardo llegara a componer «carmina amatoria» en unos momentos concretos de su existencia, su vida apasionada, rodeado de estudiantes, muchos de ellos goliardos que le seguían y aclamaban, le convirtió en una suerte de modelo para esos poetas vagabundos que anhelaban la ciencia y el goce.

Hugo de Orleans, el Primado, nació hacia el año 1093. Su fama de hábil versificador e improvisador y de poeta goliárdico le granjeó el apelativo de «Primas», el Primado, el Primate; en definitiva, el primero entre los poetas. Aunque también el hecho de ser uno de los que inició la corriente crítica contra el Pontificado, contra los obispos-primados, pudo influir en el juego de duplicidad de significados del término «primado». Fue un vagabundo permanente, aficionado al vino, las mujeres y también al sablazo, lo que le llevó a tener más enemigos que amigos, y no sólo entre la jerarquía eclesiástica. Su fama debió de ser grande en los ambientes escolares por la frecuencia con la que los cronistas de la época recogen sus anécdotas, verdaderas o falsas. De su actividad intelectual se sabe que enseñó retórica y poética en Orleans; pero lo cierto es que no tardó en emprender una vida de clérigo errante por Reims, París, Amiens o Beauvais, enseñando, componiendo versos y visitando las tabernas y a las meretrices.

La originalidad y producción de Hugo de Orleans resulta extraordinaria. Así, aunque conocía bien a los autores clásicos, y por eso a veces compuso poemas mitológicos imitando a Virgilio o a Lucano y utilizando la métrica clásica o cuantitativa, nunca tuvo reparo alguno en cantar a su amada Flora, una prostituta. Pero, sin duda, su poema más original es en el que dialoga con un capote, un abrigo raído, que le ha dado como limosna un prelado tacaño, contra quien lanza todo tipo de injurias: «Baba de los prelados, hez de los clérigos, tumor horroroso, que me has 
dado en el frío un capote sin forro». Y original es igualmente el poema en el que relata cómo un hospedero le dejó vacía la bolsa tras emborracharle y jugar a los dados con él. En el final del mismo pide a Decio —el dios de los dados y los naipes entre los goliardos - que le vengue: «Que el funesto Decio confunda a tal amigo,/ que me quitó lo mío y no me ha dejado nada» ${ }^{23}$. Otra de las singularidades de sus poemas, que acabó siendo común en el conjunto de los goliardos, es que el tratamiento dado a las desgracias personales resulta bastante leve. Se trataba de entretener, no de contar una tragedia personal. Pero los años pasan, y con ellos el aplauso, la belleza y la juventud. El Primado murió hacia 1160, viejo, cansado, aunque no parece que arrepentido de su pasado; incluso, a uno le queda la impresión de que le seguía atrayendo su antiguo modo de vida, libre, lujuriosa, intensa... pero que, sencillamente, ya no podía seguirla. Así, en su vejez nacieron los poemas más hondos, recordando con melancolía su pasado, en unos momentos en los que la pobreza, sus estancias en centros de caridad, donde no siempre era bien tratado, y los achaques de la edad constituían su día a día, lejos del glorioso y alegre pasado:

«Rico era yo y bienamado,/ preferido entre mis iguales;/ ahora la vejez me encorva/ y la edad me va consumiendo./ por eso vil y despreciado,/ hasta los desechados me desechan»; "Es mi casa el mundo entero/ que recorro vagabundo/ Antes era feliz y hablador,/ placentero y elocuente,/ jugador y jubiloso;/ entonces el primero, ahora el segundo,/ busco con rubor el alimento./ Busco el alimento con rubor,/ soy un mendigo. Pero ¿dónde/ buscaré sino entre doctos,/ yo que fui nutrido en las Musas/ y estudié con ardor bajo Homero?/Pero cuando os pida alimento de mañana/ y torne a hacerlo por la tarde,/ en breve (ya me lo temo)/ os resultaré muy gravoso a todos» ${ }^{24}$.

Del Archipoeta de Colonia, nacido al norte de los Alpes, de noble familia, hacia 1130 , se ignora su nombre. Es el «vates vatum», el poeta de los poetas, como se definía a sí mismo - la modestia nunca se consideró virtud entre los goliardos-y, probablemente, el más famoso de los goliardos, a pesar de conservarse de él sólo diez poemas. En algunos de ellos aparece el nombre de Rainaldo Dassel, arzobispo de Colonia y canciller de Federico Barbarroja, su gran protector, aunque con altibajos, desde 1161. Dassel era un hombre de excelente educación y habilidad política, a quien el poeta siguió en sus desplazamientos por Italia durante el fragor de las campañas antipapales. El Archipoeta le prestó sus servicios de amanuense y, a veces, le dedicó versos llenos de elogios, pidiéndole remedio a sus múltiples necesidades económicas. Pero él era el goliardo por excelencia, giróvago y crítico. Por eso, aunque no tuvo reparos en adular a Dassel en sus poemas cuando lo precisaba por su indigencia, resulta significativo que se negara a cantar las glorias de Barbarroja cuando en alguna ocasión se lo solicitó el canciller. Tampoco parece que le interesara el enfrentamiento existente entonces entre el Imperio y el Papado. Así, en sus viajes junto a su protector por Pavía, Salerno o Viena, el Archipoe-

23 Traducción de L. A. de VILLENA, Ob. Cit. pág. 69.
24 Ibídem., págs. 63-65. 
ta seguía practicando una vida goliardesca allí por donde pasaban, bebiendo y jugándose su peculio en las tabernas. Sin duda, le debió servir el que Dassel fuera un sincero admirador de sus versos; otra cosa no explicaría el que siguiera manteniendo ese tipo de vida y no tuviera rubor en dirigirse al arzobispo pedigüeñamente cuando lo precisaba:

«Cada cosa tiene su tiempo, y yo pido muy poco/ para poder leerte, tan sólo, unos cuantos versos./ Pues al entrar mal vestido en tan gran palacio/ no he podido sino ruborizarme como una doncella./ Salud, gran hombre, a quien se ha confiado el estado,/ cuyo consejo rige la justicia que luego se pone en práctica. / Eres la flor de los prelados y el mayor entre ellos./ Que vivas siempre incólume, hombre más sabio que Nestor ${ }^{25}$.

Su composición más meritoria, uno de los monumentos de la poesía goliárdica, es la llamada «Confesión de Golías», tanto por el uso que hace de la medida goliárdica y de su extraordinario manejo de los textos sagrados con intención paródica, como por la sinceridad desvergonzada que rezuman y la utilización de la débil condición humana como excusa para defenderse de las acusaciones vertidas contra él ante el canciller. En la «confessio» el Archipoeta pasa revista a todas sus faltas, pero recubiertas de una especie de alegato o de defensa de su posición ante el mundo; de lo que significa realmente ser goliardo. Pero también aquí muestra su lado rebelde contra la Iglesia y sus enseñanzas, al insistir en que, ya perdida su alma, sólo debe dar satisfacción a su cuerpo: «más ávido de placer que de salvación/ muerto ya en el alma, me cuido de mi cuerpo». Asimismo, su conocimiento de la liturgia se une a su genio goliardesco, al parodiar términos o frase litúrgicas, como las palabras «peccator» y «potator»(bebedor), fonéticamente similares. No es de extrañar, por tanto, que la escena de su muerte la pinte en una taberna junto a un vaso de vino y arropado por la llegada de unos ángeles, que al verle dicen: «¡Que Dios sea propicio con este bebedor!» (no con este pecador, como sería lo propio). La genuinidad de su postura ante la vida le condujo, en los momentos de desavenencia con Dassel, a tener que mendigar. Se sabe que en 1165 el Archipoeta, aquejado de alguna enfermedad, quizá venérea, viajó a Salerno por la fama de sus médicos. Después, sin dejar de estar enfermo, regresó a Colonia, donde gracias a la mano del canciller, le acogieron en el monasterio de San Martín y, quizás, fue aquí donde probablemente murió al poco tiempo, pobre y enfermo.

Gualterio de Châtillon representa al tipo de goliardo intelectual, pero timorato, indeciso. Fue un simpatizante de la causa y un compositor de poemas goliardescos, pero nunca se lanzó a vagabundear. Hombre cultísimo, nació en Lille hacia 1135. Estudió en París y Reims artes y filosofía. Fue maestro en Laón, canónigo de Reims y secretario en la cancillería de Enrique II Plantagenet, por lo que en 1166 marchó a Inglaterra, donde trabó amistad con Juan de Salisbury. En 1170 re-

25 Ibídem., pág. 78. Para sus textos latinos, véase F. ADCOCK, Hugh Primas and the Archpoet, Cambridge, 1994, págs. 68-127; y una buena y accesible introducción al poeta y traducción de algunos de sus versos, en T. JIMÉNEZ CALVENTE, Ob. Cit., 2009, págs. 148-157. 
gresó a Francia, estableciéndose como maestro en Châtillon. En esta ciudad comenzó a admirar el espíritu crítico de los goliardos, aunque nunca se atrevió a imitar su forma de vida.

Cansado de la enseñanza, Gualterio decidió ir a estudiar Derecho a Bolonia y después a Roma. En esta ciudad pudo comprobar el excesivo lujo del que vivían rodeados los prelados. Pero no era un santo, como no lo fue ningún goliardo. De tal manera que, a la vez que censuraba en sus poemas la avaricia de los simoniacos curiales, intentaba obtener algún beneficio en la capital de la Cristiandad. La crítica severa en sus versos se extremó más cuando partió de Roma sin haber conseguido prebenda eclesiástica alguna. Lo cierto es que no parece que fuera un clérigo ejemplar a lo largo de estos años, ni tampoco tras su retorno a Châtillon, donde siguió dedicándose a la enseñanza y, paralelamente, trabando amistad con goliardos vagabundos, compartiendo con ellos sus versos a la primavera y al poder del amor, así como las visitas a las tabernas y los burdeles. Sin embargo, desde 1176, año en el que el arzobispo de Reims, Guillermo de Champagne, le llamara para ser su notario, Gualterio abandonó su relativa vida goliardesca para volverse cada vez más austero, componer himnos religiosos y retractarse de las frivolidades de su juventud. Es en estos años cuando escribió su «Dialogus contra iudeos» y el «Liber de Trinitate», aunque tampoco se olvidó de las sátiras. Al final de su vida, leproso y pesimista ante la muerte cercana, y conocedor directo de la corrupción de la jerarquía eclesiástica, escribió el famoso texto que comienza "versa est in luctum/ cythara Gualterio...», donde cuenta cómo la cítara de Gualterio se ha trocado en llanto al presentir el fin del mundo. La simonía para él, en esos momentos, sólo podía representar el signo externo del final de los tiempos. En otro de sus últimos poemas se muestra ya «con miedo de la muerte inminente», por lo que ruega a Dios que tenga compasión de sus miserias pasadas ${ }^{26}$.

Buena parte de sus poemas, así como de los del Archipoeta, o los de otros goliardos, como Pedro de Blois, han llegado hasta nosotros recogidos en algunas colecciones. La más destacada y famosa de las conservadas sobre poesía latina medieval es la conocida con el nombre de «Carmina Burana» o «Codex Buranus», corrupción de Beuern, que da nombre a la abadía benedictina de Baviera, Benediktbeuern ${ }^{27}$. Los poemas se compusieron entre el siglo XII y finales del XIII, y la mayoría son anónimos. Están escritos en latín, aunque en algunos aparecen versos intercalados en dialecto alemán, por lo que se pensó en su origen bávaro. Las composiciones desarrollan los temas típicos goliárdicos: la primavera y el amor, sátiras, el vino y la taberna.

${ }^{26}$ El interés por su vida y relación con el mundo goliárdico despertó ya a fines del siglo XIX y principios del XX. Buena prueba de ello son las monografías de: R. PEIPER, Walter von Châtillon, Breslau, 1860 y de K. STRECKER, Die Gedichte Walters von Châtillon, Berlín, 1925. Véase también: O. DOBIACHE-ROJDESVENSKY, Les poésies des Goliards, París, 1931, edición de 1983, págs. 49-52.

27 El manuscrito proveniente de este monasterio se conserva en la biblioteca de Munich. Consta de 116 folios que contienen 250 poemas goliárdicos y, en menor medida, algunas composiciones en prosa y dramas religiosos. 
El Cancionero de RIpoll o Carmina Riuipullensia es el único ejemplo conservado de poesía puramente goliardesca escrito en España ${ }^{28}$. Toma su nombre del monasterio de santa María de Ripoll, fundado hacia el año 888 y foco importantísimo de actividad cultural y literaria a lo largo de los siglos XI y XII. Se conocen los nombres de algunos monjes escritores, como el del propio abad-obispo Oliva (1002-1046). Sin embargo, el autor que nos interesa es anónimo. Se trata de un monje que en las zonas vacías de un manuscrito destinado a otros asuntos escribió una serie de composiciones amorosas, unas en verso métrico y otras en ritmo acentual, probablemente a finales del siglo XII, de clara influencia francesa, tanto por su metro como por su temática, lo que no impide destacar la madurez de su autor, así como el hecho de representar uno de los mejores ejemplos de poesía goliárdica que se conserva. Se le conoce por el Anónimo o el Enamorado de Ripoll, por el contenido amoroso de sus poemas, escritos probablemente entre 1170 y 1180. Se trata de un poeta intelectual; de un gran conocedor de los clásicos, pero seducido, al mismo tiempo, por el espíritu erótico de los goliardos. Seguramente viajó por Francia y otros lugares antes de ingresar en Ripoll. En sus más importantes ciudades debió beber de los gustos y corrientes literarias del momento, en especial las de carácter amatorio. No le estimularon, por el contrario, otros temas comunes en la poesía goliárdica, como los centrados en la sátira social. Su interés gira sólo en torno al amor. Y cuando escribe parece hacerlo recordando a las mujeres que ha conocido y amado en sus viajes anteriores. Unos viajes en los que debió asimilar, sin duda, la poesía amorosa de los goliardos, como se refleja en sus poemas repletos de «topoi», tópicos comunes a toda la lírica de esta temática: el prado florido y primaveral del locus amoenus. No parece, sin embargo, que podamos dar respuesta concreta a la hora de calificarle: ¿fue sólo un poeta intelectual? ¿vagabundeó durante sus años de juventud? ¿se arrepintió de algo?

Siguiendo con los autores peninsulares, Juan Ruiz merece un tratamiento especial, a pesar de la polémica, ya antigua, sobre si el Arcipreste de Hita ha de ser considerado o no un goliardo. Menéndez Pidal ya señaló en su día que este autor no era propiamente un clérigo juglar ni un vagabundo, pero que su inspiración poética fue goliárdica, subrayando que se trataba de «un clérigo agoliardado, doneador alegre»29. Por su parte, Menéndez Pelayo subrayó que en su Libro de Buen Amor había «algo particularmente común con la poesía de los goliardos». Pero también apuntó que a Juan Ruiz le diferenciaba de ellos el hecho de apartarse de la insurrección contra la potestad espiritual ${ }^{30}$. Lo cierto es que en la obra del Arcipreste de Hita es ya del siglo XIV y, por tanto, alejada cronológicamente del tiempo propio de los goliardos, lo que no quita que en ella se observen un buen número de carac-

28 Guardado en el Archivo de la Corona de Aragón, fue publicado por primera vez por L. NICOLAU D'OLWER en 1915. Una edición posterior es la de J. L. MORALEJO, Cancionero de Ripoll (Anónimo). Texto, traducción y notas, Barcelona, 1986.

${ }^{29}$ En Poesía juglaresca y juglares. Aspectos de la historia literaria y cultural de España, Madrid, 1983 (8ª edición).

30 Otras apreciaciones de este autor sobre el Arcipreste de Hita pueden encontrarse en su Historia de los heterodoxos españoles, Madrid, edición de 1986, B.A.C. vol. I, págs. 606-608. 
terísticas goliárdicas, comunes a los Carmina Burana, tales como: el deleite en hacer chocar lo religioso y lo profano, lo burlesco y lo serio; la tendencia a adornar sus escritos con sus conocimientos de los autores clásicos y de los escolásticos; la utilización del tema primaveral ligado al amoroso; la sátira contra el clero y, en concreto, contra los miembros de la curia y más altos prelados; los amores de curas y monjas; las parodias de los rezos clericales; las propiedades del dinero, o lo imprevisible de la Fortuna ${ }^{31}$.

Sus versos goliárdicos más representativos son los que corresponden a la Cantiga de los clérigos de Talavera, donde se narra la reunión mantenida por los sacerdotes, tras conocer la carta del arzobispo don Gil de Albornoz, de claros tintes reformadores. Su temática y estructura es igual a las de la «Deliberación de los sacerdotes» o Consultatio sacerdotum, atribuido a Walter Mapp. Es posible que el Arcipreste conociera esta obra. En cualquier caso, Gil de Albornoz había convocado dos sínodos en Toledo, en 1324 y 1339, en los que exhortó al clero, bajo pena de excomunión, a abandonar a sus barraganas, y Juan Ruiz lo escribió en 1330 y luego lo revisó, ya en prisión, en $1343^{32}$. Pero, quizá, lo más interesante de los versos de contenido goliárdico del Arcipreste sea ese recuerdo ¿nostálgico? de un tiempo pasado, en el que por debajo de la piel de ese tipo de clérigo-escolar, vividor y pendenciero, existía un alma intelectual y crítica, perdida ya en el siglo XIV.

Tras estas breves pinceladas sobre determinados goliardos, que considero representativos de las diferentes categorías mencionadas respecto a su mayor o menor pureza o genuinidad, sólo resta decir unas palabras acerca del posible origen geográfico de este movimiento poético y recordar a algunos otros de fama reconocida. Todo parece apuntar que el desarrollo inicial del goliardismo tuvo lugar en Francia, más concretamente en París, el Paradisus mundi y balsamum orbis, pese a que no todos los autores han pensado siempre igual ${ }^{33}$. Sin duda, esta ciudad era privilegiada por su nutrido número de escolares y profesores, y por su especial carácter bullicioso, de manera que no es difícil imaginar que se encendiera allí la llama de la rebeldía estudiantil y poética de los goliardos. Pero lo que más interesa es que los aires de apertura y libertad que corrían por París durante la plenitud medieval, en seguida alcanzaron otras ciudades universitarias, como Orleans, Colonia, Oxford o Cambridge. En todas ellas nuestros poetas se inspiraron y dejaron sus versos, destacando los de algunos otros autores, además de los de aquellos ya comentados y los de los numerosos anónimos. Tales son los casos del arcediano de Oxford Walter Mapp, de Pedro de Blois, de Giraldus Cambrensis, de Felipe Can-

31 Sobre la influencia de los poetas goliardos en algunas partes del Libro de Buen Amor, véase la introducción al mismo, ya citada, de N. Salvador Miguel, Madrid, 1975, págs. 37-38.

32 Sobre el cardenal Albornoz se han escrito multitud de monografías, dada la complejidad de su vida; no obstante, siguen siendo títulos de referencia los estudios de J. BENEYTO PÉREZ, como El cardenal Albornoz. Hombre de Iglesia y Estado en Castilla e Italia, Madrid, 1986, y «Albornoz y sus amigos», Anuario de Estudios Medievales 18 (1988), págs. 305-317.

${ }_{33}$ Así, por ejemplo, en el siglo XIX J. BURCKHARDT apuntó Italia como la tierra de su nacimiento en su ya clásica obra La cultura del Renacimiento en Italia, Barcelona, ed. de 1971. 
cellarius, o del inglés, maestro en París y luego cisterciense, Serlon de Wilton, todos de muy diversa condición y vida, pero, todos también, consagrados goliardos ${ }^{34}$.

\section{OTRA MIRADA SOBRE LA SOCIEDAD}

Todo indica que el goliardismo fue una suerte de rebelión vital, en unas ocasiones explorada apasionadamente por sus protagonistas y, en otras, más soñada o añorada, pero siempre desde la cultura y llevada a cabo por intelectuales. Se trataba, sin embargo, de unos intelectuales que, en buena medida, se sentían ajenos al mundo estamental del Medievo en el que les había tocado vivir, aunque no por ello, según ya ha sido señalado, fueron utópicos, revolucionarios, o moralistas. Su mayor deseo consistía en cultivarse a la par que vivir de manera intensa. Su forma de sentir y de actuar, como no podía ser menos, condicionó la aparición de determinados temas en sus composiciones y la exclusión de otros, a la vez que un especial tratamiento de los elegidos para ser versificados. Gracias a ello, el casi general anonimato existente entre sus filas queda algo compensado a la hora de intentar arrojar un poco de luz sobre su perfil. Es cierto que no siempre se puede identificar lo que narran sus versos con la forma de vida de su autor pero, dado el yermo de noticias por el que debemos navegar, toda pista resulta útil para llegar a conocer si no sus peripecias personales sí, al menos, su mirada, los especiales ojos con los que contemplaron el mundo.

El primero de los temas que destaca en sus poemas es el de la propia oposición al orden social establecido, con una crítica mordaz a todos los grupos que lo integraban y se regían por sus estrictas normas. Así, su ataque a los nobles resulta paradigmático. Abelardo repudiaba el oficio militar al que estaban dedicados sus hermanos. El Archipoeta de Colonia llegó a decir «Me terruit labor militaris». Ellos, cuyo valor primordial era la inteligencia no podían entender que la nobleza se adquiriera por el nacimiento, por la sangre, considerando que la verdadera nobleza residía en la virtud y en los conocimientos adquiridos ${ }^{35}$. Su clara oposición al noble-mi-

34 Sobre la complejidad del pensamiento y de la vida de los goliardos, en general, y sobre los avatares personales de algunos de ellos, sigue siendo de referencia obligada la obra de O. DOBIACHE ROJDESVENSKY, Les poésies des goliardes, Québec, 1984 (1ª ed. París, 1931). El siguiente párrafo de la autora es muy representativo de su tesis: «...qui veut comprendre le poète goliardique ne doit pas oublier que sa main, à côté des oeuvres profanes, et au même momento, faisant naître des fleurs d'inspiration sacrée. II devait exister des raisons profondes à cette justaposition qui paraît contre nature. Ces raisons sont à chercher dans les besoins des diverses classes socials qui sìntéressaient à ces poems", pág. 240.

${ }_{35}$ El acceso a la condición nobiliaria y el propio concepto de nobleza han sido objeto de análisis por un buen número de especialistas, sobre todo, en las últimas décadas. Entre los estudios más clásicos cabe destacar los de: L. GÉNICOT, La noblesse dans l'Occident médiéval, Londres, edición de 1982; M. BLOCH, La société féodale, París, 1939-1940 (existen varias reediciones); G. DUBY, La société chevaleresque, París, 1988; C. DONATI, L’idea di nobilitá in Italia. Sécoli XIV Y XVIII, Bari, 1988; M. KEEN, La caballería, Barcelona, 1986; S. de MOXÓ, «De la nobleza vieja a la nobleza nueva. La transformación nobiliaria castellana en la Baja Edad Media», Cuadernos de Historia, 1969; J. MATTOSO, A nobreza medieval portuguesa: A familia e o poder, Lisboa, 1981; VV.AA. Origines et renouvellement de la noblesse dans les pays du Sud de l'Europe au Moyen Age, París, 1989. 
litar se proyectó en los famosos debates poéticos, como el célebre «Altercatio Phyllidis et Flore» 0»Disputa entre Filis y Flora», que influiría después en el castellano «Disputa de Elena y María». En tales debates el goliardo, el clérigo, se vanagloria por boca de una dama de ser en el amor mejor que el caballero. Flora hace la apología del clérigo como hombre sabio y respetado por sus conocimientos; Filis la hace del caballero, apuesto y galante como ninguno. Terminada la alocución de cada una de la jóvenes solicitan a Cupido que dicte sentencia: «según la ciencia y según la costumbre/ es más apto el clérigo para el amor». El goliardo, el clérigo, ha vencido. Es el triunfo de la razón y de la inteligencia frente a la fuerza y la destreza del caballero ${ }^{36}$.

Los campesinos y los burgueses también fueron objeto de su crítica. Para los goliardos los primeros eran seres rudos e incultos y, los segundos, excesivamente ordenados y avaros. De su pluma tampoco salió bien parado el estamento eclesiástico; desde el Papa y los obispos hasta los monjes y ermitaños fueron objeto de su mordacidad. Por supuesto, la alta jerarquía, los que ostentaban el poder, padeció más sus satíricos versos, por considerar a sus representantes los más alejados del espíritu evangélico, auténticas aves rapaces, además de angustiosamente normativos. Por ello fustigaron sus vicios más sobresalientes: la excesiva ambición de poder, la simonía, el nicolaísmo y la hipocresía. En los versos firmados por el mítico Golías, atribuidos en el siglo XIX a Walter Mapp, la denuncia contra los prelados resulta especialmente dura:

«Ay de vosotros que sobre la silla de Moisés estáis!/ Vosotros dictáis leyes que luego no consideráis;/ en la Iglesia el aspecto de éste adoptáis,/ cuya vida, no hay duda, luego no imitáis».

En el mismo sentido el poeta se expresa a la hora de tratar el tema del concubinato entre los clérigos:

«iOh sacerdote, a esto contesta,/ tú que, a menudo y de fiesta,/ con una esposa te acuestas,/ y después, de mañana, misa dices,/ el cuerpo de Cristo bendices,/ tras abrazar a una buscona, / no tanto como tú, pecadora» ${ }^{37}$.

Pero, como ya se apuntó, su crítica desatada no impedía, en cuanto que no eran moralistas, que cuando el hambre o la necesidad apremiaban dudaran a la hora de tener que escribir un panegírico a algún obispo, como en el caso del Archipoeta de Colonia. El Archipoeta, ante la situación de hambre y frío por la que atravesaba en el año 1162 tras haber huido de su protector Reinaldo Dassel, canciller mayor de Federico Barbarroja, no vaciló en dedicarle un encendido y elo-

36 Un buen ejemplo de la proyección posterior que tuvieron estos debates puede verse en R. MENÉNDEZ PIDAL, «Elena y María (Disputa del clérigo y el caballero). Poesía leonesa inédita del siglo XIII», en Tres poetas primitivos, Buenos Aires, 1948.

${ }_{37}$ Ambas traducciones en: T. JIMÉNEZ CALVENTE, Ob. Cit. pág. 44. Sobre el tema del celibato eclesiástico y las barraganas, véase: A. ARRANZ GUZMÁN, «Celibato eclesiástico, barraganas y contestación social en la Castilla bajomedieval», Espacio, Tiempo y Forma. Revista de la Facultad de Geografía e Historia. Serie III, 21 (2008), págs. 13-39. 
gioso poema de arrepentimiento, en donde le compara con distintos personajes de la antigüedad clásica grecolatina e, incluso, con San Martín por su conocida generosidad. Su propósito no era otro que el de ser acogido de nuevo por el prelado:

«(...) Eres la flor de los prelados y el mayor entre ellos/ Que vivas siempre incólume, hombre más sabio que Néstor./ Te ruego, varón justo y piadoso, me admitas un consejo,/ a ti de tan recto juicio, y a quien todos honoran./ Es costumbre de los grandes proteger a los modestos,/ Abre tu corazón a afligidos, según tu probidad te enseña./Ayuda con tu sabida piedad a quienes vivimos en indigencia, / y como tramontano que eres ayuda a los tramontanos./ Mi sola esperanza en la vida es la que coloco en ti./ Que el frío y el hambre alejen su diente de mí (...)»38.

Pero los goliardos no sólo criticaron a los prelados; los monjes y los ascetas fueron igualmente objetivo de sus afilados verbo y pluma. Un goliardo, amante por encima de todo de la vida intensa, no podía entender ni la soledad del yermo, ni la pobreza voluntaria, ni la continencia, ni la obediencia a un abad. Para ellos tales características o votos no representaban virtudes, sino la negación misma de la vida. Sin embargo, no deja de ser curioso que dentro de las composiciones denominadas «disputas poéticas», abundantes en la literatura latina medieval y alguna especialmente famosa como la ya mencionada de Filis y Flora, la conocida como «El escolar y la monja» finalice con una solución conciliadora protagonizada por el escolar. En concreto, éste convence a la religiosa, que le ha ofrecido su «nívea carne» y sus «blancas piernas» ocultas bajo el hábito, del grave pecado que supondría «violar una esposa de Dios», a lo que la monja le responde:

«Has vencido nuestra pasión con santos argumentos./Me alegro de haber sido convencida por tus palabras»39.

Otro de los argumentos favoritos de sus poemas era el relato de la experiencia personal. La ausencia de pudor a la hora de describir escenas de su propia vida nos permite conocer algo más sobre su especial mundo. Nos hablan de sus viajes y hospedajes, más o menos cómodos o infortunados y también de sus compañeros de andanzas y juergas, de los vagabundos, bufones o comediantes con los que se mezclan; de la necesidad de pedir limosna, en ocasiones, y de la rapidez con la que gastan el dinero en el juego, el vino o las mujeres; asimismo, relatan cómo, a veces, se ponen, o sueñan con hacerlo, bajo la protección de un gran señor. Se trata, en buena medida, de una poesía de la experiencia, en la que el poeta narra sucesos vividos en primera persona.

De la estación primaveral también se alimentaron sus versos ¡Es la estación de la vida! Para los goliardos, la llegada de la primavera siempre representó el retorno al camino, el volver a vagabundear, olvidando las tareas propias del estudiante que

\footnotetext{
38 Traducción de L. A. DE VILLENA, Ob. Cit. pág. 171.

39 «Vicisti nostrum sancta ratione furorem:/ gaudeo quod verbis sum superata tuis». Una traducción completa del texto en: R. ARIAS Y ARIAS, La poesía de los goliardos, Madrid, 1970, pág. 257.
} 
ansía abandonarlas, al menos temporalmente, para dedicarse a cantar a los árboles y a los prados; para gozar del buen tiempo y de los encuentros amorosos. En sus canciones con esta temática aparecen toda una gama de «topoi» clásicos, como el «carpe diem»:

«Dejemos los estudios,/ es dulce la desidia/ y gocemos los placeres/ de la juventud tierna;/ que es propio de la vejez,/ entender en cosas serias».

¡Vivamos la primavera estacional y vital!, parecen gritarnos en sus versos. Describen la hierba que renace, el canto de la filomena (filomela o ruiseñor), el color y el aroma de las flores, creando un lugar idílico que consigue que la sangre se incendie, y posibilita y adorna los encuentros amorosos y eróticos. Las canciones de primavera son muchas:

«Ya los prados ríen,/ ya se alegran las doncellas, y sonríe/ la faz de la tierra,/ ahora llegó la primavera/ y alegre brilla ornada de flores» ${ }^{40}$.

Es interesante recordar que en la lírica medieval el tema del amor no ocupó un verdadero lugar hasta el siglo XII. A partir de esta centuria, sin embargo, empezaría no sólo a irrumpir con brío en la poesía, sino también a convertirse en el tema poético por excelencia, y tanto para quienes versificaban en latín, como para quienes lo hacían en romance. Pero el amor en la poesía goliárdica es diferente al narrado por otro tipo de poetas, y también lo son sus apreciaciones sobre la mujer. Hasta el siglo XII la imagen de la mujer no había sido especialmente agradable. Muy al contrario, la mujer solía aparecer en la mayoría de los escritos como origen de todos los vicios y perversidades. Era Eva. La misoginia se muestra, pues, en numerosas páginas medievales. Así, en unos hexámetros dactílicos atribuidos al arzobispo de Tours Hildeberto de Lavardin (1055-1133) la imagen que se proporciona de la mujer no necesita aclaraciones: «Femina perfida, femina sordida, digna caetanis. Mens male conscia, mobilis impía, plena veneris "41. En el mismo grupo antifeminista hay que situar al obispo de Sens, Pedro de Corbeil (1150-1220), a quien se le atribuye una composición satírica titulada «Adversus eos qui uxorem ducunt». Mucho tiempo después, en nuestra tierra, y en castellano, se dieron frutos similares, como las descripciones sobre las mujeres salidas de la pluma del arcipreste de Talavera, Alonso Martínez de Toledo, en «El Corbacho» (1498) quien, entre los muchos denuestos salpicados por sus páginas, dedicó todo un capítulo a «lo muy engañoso que es el amor de la mujer» ${ }^{42}$.

No obstante, lo cierto es que el siglo XII representó un cambio en el tratamiento de la mujer y del amor. Por un lado, gracias al desarrollo de la devoción mariana y a los escritos que se generaron en torno al tema, como los de San Bernardo, la

\footnotetext{
40 Traducción de L. A. de VILLENA, Ob. Cit., págs. 181-182.

41 MIGNE, Patrología Latina, 171, 1428.

42 Prólogo y notas de A. del SAZ, Barcelona, 1977, págs. 5-40 y 83-88.
} 
casi exclusiva imagen que se tenía de la mujer, como una Eva pecadora, fue siendo desbancada por la de la Virgen María, con la exaltación de la pureza y la virtud transcendente de la mujer madre. Por otro, gracias al nuevo enfoque sobre la mujer presentado por la lírica en lengua vernácula, occitana, en la Provenza. Aparece el «amour courtois», un nuevo concepto de amor de corte romántico en el que los trovadores fundieron una serie de elementos sacados de la realidad, de su entorno social: el código de caballería, que obligaba a proteger a los débiles, entre los que se hallaba la mujer; el mismo feudalismo, con la identificación del amante como vasallo de su amada; la importancia adquirida por el tratado sobre la conquista amorosa de Ovidio, el «Ars amandi»; la propia estrategia militar empleada en el Medievo también se utilizó para comparar la conquista de la amada con el asalto a una plaza fuerte tras un largo asedio. Todo ello repercutió en la aparición de una nueva imagen, al menos intelectual, de la mujer y de las relaciones amorosas. Los goliardos fueron coetáneos de esta corriente poética, así como del desarrollo de la devoción mariana y, por supuesto, ellos tampoco vieron ya a la mujer como causante de todos los males. Pero su movimiento poético entrañaba profundas diferencias con el protagonizado por los trovadores y, en consecuencia, el tema de la mujer y el del amor tuvieron un tratamiento distinto. Era lógico que así fuera, porque el origen social y los radios de acción de goliardos y trovadores estaban muy alejados. Los goliardos eran gente de estudio, vinculados a escuelas y universidades, los trovadores no; los primeros se movían por los caminos y las tabernas, mezclándose con todo tipo de mujeres; los segundos lo hacían por palacios y cortes, dirigiendo sus versos sólo a las damas.

El trovador era galante, veneraba a la dama que, casi siempre, resultaba inalcanzable; el goliardo contemplaba a la mujer de carne y hueso. Su amor y su verso no respondían a teorías ni a códigos establecidos. Valoraba su belleza física y la detallaba sin evitar parte alguna del cuerpo (ojos, mejillas, pechos, muslos...) pero, además, su fin no era la descripción sin más de la hembra, sino, y por encima de todo, la de su posesión, la sensualidad que la envuelve y el deleite obtenido con la misma. Por eso, en sus pastorelas, como, por ejemplo, en las de Gualterio de Châtillon, o en las del Enamorado de Ripoll, no encontramos ademanes cortesanos; sus enamoradas son muchachas bellas y sencillas, pastoras verdaderas que, a veces, toman la iniciativa amorosa, cosa que no ocurre en la pastorela cortés. Tampoco existe en sus versos una especial delicadeza, incluso, en ocasiones, pecan de exceso de rusticidad como, en esas invitaciones directas realizadas por las pastoras a los goliardos para que vayan a retozar juntos. Algo impensable en el entorno del amor cortés. Cada parte del cuerpo es llamada por su nombre y el fin del encuentro amoroso siempre es el lecho. Los versos del Enamorado de Ripoll son un buen ejemplo:

«(...) Busque pues cada cual quien le ame,/ y ame según sea amado./ La honesta doncella busque/ un amigo conveniente y joven,/ y que quiera de igual modo/ amar como ser amado./ Que el joven y la doncella hermosa/ en la oscuridad el lecho opriman/ y con frescura enlazados,/ se den dulces abrazos./ Y que mientras la tiene/ 
bese el joven boca y mejillas;/ palpe el pecho y los pezones/ y la cosa pequeñita,/ juntando muslo y muslo,/ consumando el fruto de Venus./ Que cese entonces todo ruido,/ el amor así se consuma» ${ }^{43}$.

Pero no fueron sólo las doncellas y las pastoras las únicas mujeres inspiradoras de sus versos, también las prostitutas ocuparon un importante papel en ellos. La descripción que hicieron de burdeles y meretrices del Medievo permite comprobar al historiador actual la sordidez del entorno en el que se desenvolvían los goliardos genuinos, así como la más que negra visión que tenían de estas mujeres, en un claro enlace con la larga tradición de poesía misógina existente. La descripción realizada por Hugo de Orleans, el Primado, sobre las maneras y forma de vida de una prostituta resulta más que elocuente. El Primado articula el poema en dos partes contrapuestas, aunque ambas cargadas de ironía y desprecio hacia este grupo de mujeres, a quienes, de acuerdo con la visión del poeta, sólo interesan el vino y el dinero. En la primera de ellas describe las formas engañosas de las que se reviste la prostituta cuando sale del burdel para visitar a un cliente acaudalado; en la segunda, ofrece un cuadro lúgubre de la penosa y repugnante realidad en la que habita la mujer de vuelta a su casa: «(...)

Y partiendo un trocito de pan duro, lo moja en salsa/ recalentada, que guisó la noche pasada./ Entonces vinazo malo, en que flotan heces, ella adquiere (...) A la voz del cantinero, ella, temerosa de la riña, se acelera;/ fea y desaliñada, pronta a correr tras el mamarracho./ A cualquier juego inmundo que él propone, ella no se opone;/a la espera de una paga, en establo maloliente mete su cara./ Donde llevársela quiera, presta irá por amor a la módica moneda;/ como la abeja que a la miel se pega y es imposible de arrancar,/ así vuela la puta hacia el dinero que un truhán le quiera dar,/ y si le paga, con cualquier sandio se va a la cama» ${ }^{44}$.

De los versos satíricos de los goliardos tampoco lograron zafarse las doncellas casaderas. Los versos de crítica abierta hacia ellas y, más concretamente, hacia la institución matrimonial, gozaron de enorme éxito a lo largo del Medievo. Uno de los poemas sobre el tema, que alcanzó gran fortuna y de autor anónimo, narra la intención de casarse de un hombre con una mujer, a la que califica de «joven tierna, hermosa y de gran valía». Pero el hombre tiene la visión de tres ángeles, enviados directamente por Dios, que van tomando la palabra y desgranando argumentos para intentar convencer al incauto joven de no casarse:

«Hace algún tiempo, con una muchacha casarme quería (...) Algunos amigos entonces me aconsejaban/ que prisa me diera y me casara;/ la vida matrimonial sin cesar me alababan/ para que de sus miseria también yo participara (...) Deseaba

43 Traducción de L. A. DE VILLENA, Ob. Cit. pág. 182. El conjunto de la misma en: J. L. MORALEJO, Cancionero de Ripoll. Texto, traducción y notas, Barcelona, 1986. Un buen análisis sobre la lírica amorosa en el Medievo y, en concreto, sobre los poemas de amor de los goliardos en: E. MONTERO CARTELLE, Carmina Burana. Los poemas de amor, Madrid, 2001.

44 Traducción de T. JIMÉNEZ CALVENTE, Ob. Cit. pág. 109. 
someterme por tiempo eterno,/ y a múltiples penas ofrecer mi cuello,/ pero hasta mí llegó la caridad del magnífico Padre,/ bajo la forma de tres ángeles» 45 .

Su mensaje es claro: todo en la mujer son vicios, y el matrimonio arruina al varón. Quizá, por ello, buscaron sobre todo la unión carnal con vírgenes adolescentes y frágiles, todavía según ellos, alejadas de comportamientos tramposos y, por supuesto, del mundo de las meretrices. Un poema de los Carmina Burana refleja esta inclinación:

«Ludo cum Caecilia,/nihil timeatis;/sum quasi in custodia/ fragilis aeatis,/ ne marcescant lilia/ suae castitais.../ Gratus super omnia/ ludus est puellae.../ Ludo cum virginibus,/ horreo corruptas,/ et cum meretricibus/ simulo di nuptas,/ nam in istis talibus/ turpis est voluptas» 46 .

Retozar con una doncella, con una virgen, es lo más grato de todo, a fin de que no se marchiten los lirios de su castidad, escribe el goliardo, frente al horror que le producen las prostitutas.

Sin embargo, todo parece indicar que los goliardos fueron asiduos clientes de los burdeles, porque con las meretrices, aun sabiendo de su dedicación fingida, de su excesiva pasión por el dinero, podían medir su «extraordinaria» virilidad; y si hay algo que caracterizaba a estos poetas era la vanidad, en cualquier campo de la existencia, cultural o personal. Las siguientes estrofas, pertenecientes a un largo poema recogido en los Carmina Burana, sintetizan ambas ideas:

«Se despojó de sus vestidos la madre del Amor,/ para mostrarme sus carnes de níveo color./ Tras echarla en el lecho diez horas casi sin interrupción/ mitigué la rabia de mi febril ardor (...) Tres meses, creo, con ella me he quedado;/ mientras tenía el bolsillo lleno, fui varón agasajado,/ Al separarme de Venus, me veo despojado/ de mi dinero y mis vestidos; estoy totalmente esquilmado».

El poema en su conjunto relata las peripecias de un joven poeta incauto que, tras beber en la taberna, entra en el burdel y solicita ser llevado ante la misma Venus, diosa de ese templo y la única que puede apagar su ardor. En el burdel come, bebe, fornica, eso sí, sólo hasta que el dinero se acaba ${ }^{47}$.

Las canciones sobre la taberna y el juego fueron especialmente características del mundo goliárdico. El vino también había sido cantado por los poetas de la Antigüedad, pero no parece que existiera demasiado influjo de la lírica báquica clásica en los versos goliardescos. Éstos, más que del vino, hablaban de la taberna, como lugar especial, de mala reputación, pero muy visitado y querido por ellos. Es

\footnotetext{
45 Sobre el éxito del poema, las numerosas copias y traducciones que se hicieron de él, así como lo común de las sátiras contra las mujeres, véase M. PUIG RODRÍGUEZ-ESCALONA, Poesía misógina en la Edad Media Latina (siglos XI-XIII), Barcelona, 1995 y, en concreto, las páginas 223-250.

46 J. A. SCHMELLER, Carmina Burana, Sttutgart, 1847, págs. 151-152.

47 J.A. ESTÉVEZ SOLA, Carmina Burana, Antología, Madrid, 2006, págs. 123-128.
} 
el marco para divertirse, emborracharse, cantar sus poemas, jugar a los dados y abrazar a las mujeres de vida alegre. Probablemente sean estos poemas tabernarios los más representativos de este movimiento, ya que en ellos se muestra más que en otros la combinación de su espíritu rebelde, crítico y a la vez vividor, en cuanto que elogiar estos lugares, estos ámbitos amorales, significaba una auténtica transgresión. Alabar la gula, el juego, el vino, incluso, parodiar la liturgia rompía con todo el orden establecido. Uno de los más famosos poemas, «In taberna quando sumus», es una fantástica descripción del vitalismo goliárdico:

«In taberna quando sumus,/ non curamus quid sit humus.../ Quidam ludunt, quídam bibunt,/ quídam indiscrete vivunt...».

Parecían tenerlo claro: el vino estaba gloriosamente enraizado en la cultura occidental, también en la religión. Como clérigos e intelectuales conocían muy bien la Biblia, texto sagrado salpicado de referencias a esta bendita bebida desde principio a fin, aunque con diversos sentidos. En el Antiguo Testamento, en el mismo Eclesiástico, según el capítulo y el versículo, hay para todos los gustos: «No te hagas el valiente con vino, porque a muchos perdió la bebida»; «El vino es la vida para el hombre si se bebe con moderación»; «¿Qué vida es la de los que del todo carecen de vino? Fue creado para alegría de los hombres»"4. Los goliardos, evidentemente, no eligieron el camino de la moderación, llegando a burlarse en ocasiones de ciertas prácticas de la liturgia. Así el Archipoeta escribía:

«Con la bebida se enciende la chispa del alma,/ lleno el corazón de néctar se eleva a las alturas,/ y me es más agradable el vino de la taberna/ que el que mezcla con agua el copero del prelado».

Los Carmina Burana también recogen un poema vinculado a las celebradas altercationes o disputas entre el agua y el vino, en el que el goliardo habla de la unión en su copa de Tetis, representación del agua, y Lieo, el dios Baco, con una mayor proporción del agua, lo que se traduce en un verdadero desastre:

«In cratere meo Tetis est sociata Lieo:/ sic dea iuncta deo, sed dea maior eo./ Nil valet hic vel ea, nisi cum fuerint pharisea...»49.

Otro de los temas más representativos de nuestros poetas es el referido a su sentido de comunidad. Una comunidad no conscientemente estructurada, aunque sus componentes -escolares vividores- serían, según sus personales criterios, los únicos individuos de la sociedad, junto con los maestros, dignos de elogio. Esto no quita que en su famoso «Himno de los vagabundos» se hable de «secta» y llamen a integrarse en ella a todo el mundo. Sólo se les pide «Probad todas las cosas y examinad bien vuestro modo de vida». Después todos son invitados a pertenecer a la misma: el monje pobre, el clérigo con su manceba, los cojos y los débiles, los

48 Eclesiástico, 30, 31-32, y 31, 33-35.

49 Cf. Poema 194 de los Carmina Burana. 
justos y los injustos, los jóvenes y los ancianos, a los fríos y a los que se abrasan en el fuego de Venus, a los mansos y a los locos, a los belicosos y a los pacíficos. Todos encuentran su sitio y «nuestra hospitalidad no excluye a nadie». Pero lo cierto es que se trata, sencillamente, de una canción eufórica, pero carente de realismo. Porque los goliardos eran también vanidosos y soberbios, ¿cómo iban a adoptar al rudo campesino o al normativo burgués, en definitiva, al analfabeto? Quizá lo hicieran, pero para una juerga costeada por los otros.

Varios códices recopiladores de poemas goliardescos se hallan ilustrados con la rueda de la Fortuna. Y es la Fortuna, imagen de mudanza del mundo, la del cambio constante, la «imperatrix mundi», en la que viven estos clérigos vagantes, otro de los temas más destacados de sus composiciones. En la Antigüedad la Fortuna, hija de Júpiter, se representaba como diosa, junto con otros atributos, como el cuerno de la abundancia. En la Edad Media se simbolizaba con una rueda y el lema «era, es, seré, he sido», y con figura de rey y el verso «regnabo, regno, regnavi, sum sine regno». Es la rueda que rige los cambios del mundo, la desgracia y la suerte, siempre inconstante, siempre mudable como la luna. La Fortuna lo trastoca todo. El goliardo, en ocasiones, canta su mala suerte, pero sabe que no le queda otro remedio que someterse a ella:

«O Fortuna,/ velut luna/ statu variabilis,/ Semper crescis/ aut decrescis ${ }^{50}$.

Un último tema dentro de la poesía goliárdica, aunque menos común y más complejo, es el del miedo, el de los posibles miedos del goliardo ¿Temían a algo los goliardos? ¿qué podía aterrorizar o intimidar a estos hombres tan vitalistas y de vivir despreocupado? Es difícil saberlo, pero algunos de sus versos ofrecen ciertas claves. Podemos mencionar un temor menor y un miedo mayor. El primero estaría relacionado con la miseria. Es cierto que el goliardo, como se acaba de señalar, reconocía lo mudable de la Fortuna y, además, asumía esa realidad ¿Cómo no hacerlo tras abrazar un tipo de vida como el suyo?, ¿cómo no pensar en el hambre y en la pobreza? cuando en el fondo sabían que tales desdichas representaban el precio que debían pagar por vivir en libertad. Sin embargo, casi todos sus poemas reflejan una sensación de cierta ligereza a la hora de tratar sus personales situaciones adversas. Quizá, porque para la mayoría se caía tan fácilmente en la indigencia como se podía salir de ella. En el juego y, probablemente también en otras prácticas de escasa moralidad, pueda encontrarse alguna respuesta. No era extraño que en una partida perdieran todas sus posesiones, pero también que las incrementaran, por lo que resulta complicado percibir en sus versos una auténtica sensación de angustia. Además, cabe pensar en la existencia de una cierta camaradería, tanto en la bonanza y en la juerga, como en la necesidad inmediata. No obstante, si no se aprecia un claro temor en todos ellos, sí quedan determinadas

50 Carmina Burana, fol. I. Cit por R. GARCÍA VILLOSLADA, La poesía rítmica de los goliardos medievales, Madrid, 1975. El autor recoge también la representación señalada del rey y su lema, pág. 49. 
muestras, unas más leves que otras. Recordemos cómo el Archipoeta, tras un período de alejamiento del canciller Dassel y haber padecido la necesidad del alimento cotidiano, no dudó en escribirle un panegírico donde, tras calificarle de «flor de los prelados y el mayor entre ellos» solicitaba abiertamente su ayuda:

«Es costumbre de los grandes proteger a los modestos./ Abre tu corazón a afligidos, según tu probidad te enseña./ Ayuda con tu sabida piedad a quienes vivimos en la indigencia/ ... Que el frío y el hambre alejen su diente de mí».

Pero la pobreza puede tener remedio, lo que no lo tiene es la vejez y la muerte. Todos sabemos que lo único cierto que nos espera al final del camino es la parca. Sin embargo, los goliardos en sus poemas no transmiten la sensación de temerla demasiado, ¿para qué?; la muerte es inevitable. Por ello, también el Archipoeta, al plantearse la salvación eterna y el modo en que debía recorrer su existencia, no lo dudó: «más ávido de placer que de salvación/ muerto ya en el alma, me cuido de mi cuerpo». Su forma de vida es pecadora, pero su ruta, su camino, es chispeante y, por tanto, el único que merece la pena seguir.

Ahora bien, si no parece haber entre ellos un miedo concreto a la muerte, sí lo encontramos en relación con la vejez, con la enfermedad y, en especial, con el inevitable cambio de vida al que obligan ambas realidades. Eran esa metamorfosis, esa vejez y esa enfermedad, los mayores males que podía padecer un goliardo vagabundo y juerguista y, por tanto, sus auténticos temores. Durante la juventud había oportunidades para paliar la pobreza, cambiar la suerte; en la vejez, sólo les quedaba mendigar a quienes finalmente no quisieron o no pudieron situarse en la sociedad. Y mendigar, a estos seres altivos, vanidosos y, a veces, soberbios, les producía sonrojo, vergüenza. Hugo de Orleans, el Primado, reflejó perfectamente este sentir en los versos citados arriba «Antes era feliz y hablador,/ placentero y elocuente,/ jugador y jubiloso:/ entonces el primero, ahora el segundo,/ busco con rubor el alimento». El rubor aparece porque es consciente de que a él, «nutrido en las Musas», que estudió con ardor a Homero, no le queda otro remedio que pedir limosna entre los doctos; pero sabe que sus jóvenes y cultos compañeros acabarán por encontrarle «gravoso». El «fugit irreparabile tempus» frente al «carpe diem» hace su aparición. La primavera de la vida huye veloz para dejar paso al invierno, un triste invierno, porque el goliardo sabe que aunque la primavera estacional volverá y los prados se cubrirán nuevamente de flores, y en ellos retozarán otros jóvenes, en su cuerpo ya sólo reinará el invierno y la enfermedad:

«La salud sufre daño,/ se enfría la sangre, el corazón se embota/ disminuyen los goces,/ y la vejez nos aterra/ con su multitud de males» ${ }^{51}$.

Algunos de nuestros poetas fueron tan conscientes de ello que cedían el paso, no sin tristeza y melancolía, a los jóvenes:

51 Véase nota 25. 


\begin{abstract}
«Mientras la fortuna quiso que fuera bienaventurado,/ por aspecto y buenos modales me hizo estimado (...) Después pereció la flor de mi juventud/ y todo se llevó el tiempo de la senectud (...) En la trilla de las doncellas se lleva el anciano/ la paja como galardón y el joven el grano;/ Así que a mi sucesor la era dejo, ya entrado en años»52.
\end{abstract}

Aunque, en menor medida, también han llegado hasta nosotros algunos ejemplos de arrepentimiento ante la muerte inminente, como el que nos proporciona Gualterio de Châtillon. En su poema el goliardo pide perdón a Dios por sus pecados ¿Puede verse en ello temor a los castigos eternos por su vida disoluta? En él ya no se muestra el hombre vanidoso, ni el intelectual que ha sido, sino un hombre desnudo, enfermo y próximo a la muerte, pero a la vez creyente; en él, en definitiva, aparece el cristiano que suplica compasión al Padre:

«...con miedo a la muerte inminente/ invoco al Señor./ Ten piedad de mí, oh Dios,/ que soy miserable y reo./ Estoy uncido al yugo/ pesado de mis delitos/ y nutrido de la vieja levadura,/ a ti te suplico»53.

\title{
EL FINAL DE LOS GOLIARDOS: CLÉRIGOS VAGABUNDOS Y «CLÉRIGOS FALSOS»
}

Desde mediados del siglo XII el goliardismo, poco a poco, se fue debilitando hasta agotarse en la centuria siguiente. La estrecha unión de su peculiar forma de vida y de su manera de componer se desvaneció. Muchos clérigos continuaron recorriendo los caminos, pero se trataba sólo ya de clérigos vagabundos, en su mayoría al margen de los anhelos intelectuales de tiempos pasados. La valoración del latín y de la cultura, en general, entre estas gentes había pasado a un lugar muy secundario o, sencillamente, había dejado de interesar. Sólo parecían buscar saciar sus apetitos carnales: beber, cantar poemas o hacer de histriones y saltimbanquis cuando la situación era propicia. Si el dinero escaseaba, se podían convertir en auténticos tahúres, siendo más que frecuentes las peleas y la sangre en las jugadas con apuestas de dados o naipes. Ya no quedaba un trasfondo de rebeldía, ni un entendimiento filosófico del significado de la libertad, de lo que los goliardos habían entendido por el buen vivir, en esa suerte de combinación entre la taberna y la nutrición que extraían de las enseñanzas de los más sobresalientes maestros. El goliardismo fue agonizando hasta dejar de existir, dando paso, primero, a un subgrupo de clérigos vagabundos, cuya existencia, no obstante, había sido ya denunciada muchos siglos atrás, concretamente, en el concilio de Nicea del año 325, donde se había anatemizado a todos aquellos que tras entrar en religión se dedicaran a vagabundear y, segundo, a los denominados "clérigos falsos". Desde el primer concilio ecuménico, los monjes errabundos e inestables, como lo

\footnotetext{
52 Traducción de E. MONTERO, Carmina Burana, pág. 166.

53 Traducción de L. A. DE VILLENA, Ob. Cit. pág. 87.
} 
demuestran la cantidad de denuncias llevadas a cabo en asambleas posteriores, siempre serían objeto de desconfianza para la Iglesia ${ }^{54}$. Pero no sólo fueron los concilios los que se preocuparon del tema, sino también eclesiásticos e intelectuales de la talla de San Agustín, gran fustigador de los que marchaban del monasterio y eran remisos al trabajo. Lo mismo hay que decir de San Benito, quien en su famosa regla dejó una elocuente descripción de los mismos:

«el cuarto linaje de monjes es el que llaman giróvago, que giran toda su vida por provincias, hospedándose tres o cuatro días en diversas celdas, siempre vagos, nunca estables, esclavos de la gula y de sus placeres».

No hay que olvidar que para la Iglesia la stabilitas loci de los monjes no sólo era un distintivo, sino que también se entendía como una necesidad jurídica. La descripción de San Isidoro sobre estos clérigos en su De officiis ecclesiasticis es aún más detallada, al sentirlos como una de las grandes lacras padecidas por la Iglesia:

«Libres e inestables, no hacen otra cosa que abrazar una vida torpe y vagabunda. Con tal de conseguir satisfacer sus placeres, sin temor a nadie, se dejan arrastrar por la libertad y por sus deseos como brutos animales, portadores del signo de la religión, pero sin ejercer ministerio alguno, semejantes a los hipocentauros, ni hombres ni caballos» 55 .

La legislación civil altomedieval, aunque en menor medida, se ocupó igualmente por el tema de los clérigos vagabundos, como lo demuestran las alusiones a los mismos en la Admonitio generalis y las Capitulares de Carlomagno de los años 789 y 797 . Se trataba, pues, de un colectivo dentro del estamento eclesiástico, nada desdeñable desde el punto de vista cuantitativo, cuyos integrantes se parapetaban tras la tonsura y el hábito y que serían una y otra vez denunciados, siglos después, por los ciudadanos a causa de la cantidad y gravedad de las malfetrías que perpetraban. Constituían también un subgrupo de marginados como los goliardos, pero con los que no han de confundirse. Porque en el goliardismo siempre fueron inseparables la intensidad del vivir con la intensidad del saber. Se trataba, en definitiva, de una realidad ya antigua, formada por clérigos errabundos, gentes de mal vivir, «fazedores de escarnios» y ajenos a la cultura. Esto no quita que el espíritu goliardeso se mantuviera vivo en poetas tardíos, como el mencionado Arcipreste de Hita en el siglo XIV, o François Villon en Francia, o Ál-

${ }^{54} \mathrm{H}$. WADDEL registró 88 concilios en los que se trató el tema de los clérigos vagabundos y vividores en The wandering scholars, Londres, 1932. Aunque no he llevado a cabo un recuento detenido de las alusiones a este tipo de personajes en los sínodos diocesanos de la Corona de Castilla, no me cabe duda de que su número se incrementaría enormemente, en función de las veces en que aparecen términos sinónimos, como he podido comprobar al realizar algunos estudios sobre diferentes aspectos de la vida cotidiana del clero. Cf. A. ARRANZ GUZMÁN, «Fiestas, juegos y diversiones prohibidos al clero en la Castilla bajomedieval», Cuadernos de Historia de España, Buenos Aires, 2004, págs. 9-33.

55 Cf. Santos Padres españoles. II San Leandro, San Fructuoso, San Isidoro, B.A.C. Madrid, 1971, pág. 90, y Regla del gran patriarca San Benito, ed. Abadía de Sto. Domingo de Silos, Burgos, 1993, pág. 21. 
varez de Villasandino en la Castilla en el XV, quienes, de alguna manera, recordarían lo que habían sido y representado aquellos especialísimos poetas. Y lo mismo hay que decir respecto a la conservación de su técnica, pero ya como vehículo de expresión de la poesía religiosa y la himnología litúrgica, en los llamados «goliardos a lo divino», cuyos nombres sí que se conocen perfectamente ${ }^{56}$.

Nos encontramos, por tanto, ante la existencia de eclesiásticos vagabundos desde prácticamente los inicios del Cristianismo, cuya presencia volvió a ser denunciada, con más intensidad si cabe, en los últimos siglos del Medievo y, a veces, de manera conjunta con la de los llamados «clérigos falsos», dejando en medio un breve período de tiempo en el que convivieron con los goliardos y su especialísima forma de entender la vida. Unos goliardos que, a diferencia de ellos, acabaron por desaparecer en pocas décadas y que, desde hace ya mucho tiempo, han venido despertando el interés de no pocos estudiosos por conocer el porqué de su eclipse y posterior desvanecimiento. Sin pretender ofrecer respuestas definitivas, y compartiendo parte de los argumentos presentados por algunos investigadores, considero que en su final concurrieron, al menos, tres factores determinantes. En primer lugar, su propio deterioro interno, ya que al no ser revolucionarios, sino anárquicos, carecieron de una estructura única, de una normativa -los principios de los «hermanos» goliardos, enunciados en algún poema, sólo pretendían hacer reír- que les cohesionara. Así, del mismo modo que nacieron al calor del desarrollo plenomedieval en todas sus vertientes, su sincera rebeldía inicial, y muy personal, se fue diluyendo con el paso del tiempo. Los aplicados y laboriosos se dedicarían sólo a estudiar, y los vagabundos sólo a vivir en la pobreza y/o en el escándalo. Lejos de esta nueva realidad quedó, por tanto, su peculiar e inteligente equilibrio, vivido, recordado o soñado, entre el amor por la cultura y la poesía y su devoción por la taberna y las mujeres.

En segundo lugar, la presión social, iniciada por la jerarquía eclesiástica, continuada por los poderes laicos y finalizada, cuando ya el goliardismo había dejado realmente de existir, por las protestas ciudadanas, que realmente iban dirigidas hacia otro tipo de personas, les propinaría la puntilla. El choque con la institución eclesiástica era inevitable, ya que al ser tonsurados, o incluso tener órdenes, dependían de ella. Al principio, ni Roma, ni en general el alto clero, dieron demasiada importancia a este fenómeno. Porque, según acabamos de apuntar, clérigos vagabundos siempre existieron, y en el caso de estos clérigos escolares, la experiencia les debió llevar a considerar que sus excentricidades pasarían tan rápidas como su juventud. Sin embargo, esta indiferencia inicial no tardaría en convertirse en un progresivo rechazo. Sin duda, la extensión geográfica del movimiento, la cada vez mayor relación con gentes de mal vivir, siempre rozando el delito y, sobre todo, la crítica abierta a la jerarquía eclesiástica en sus poemas, resultaron definitivos para que, primero, se les considerase como unos marginados más y, después, se em-

56 Valgan como ejemplo los nombres de Juan de Garlandia, Ricardo Rolle o Juan de Howen. Cf. M. MARCOS CASQUERO, Ob. Cit. pág. 79. 
pezara a legislar duramente contra ellos. Curiosamente, cuando esto ocurrió, a mediados del siglo XIII, el goliardismo ya había prácticamente desaparecido por la pérdida de su esencia intelectual y de su sentido crítico de los comienzos. Su poesía seguía interesando, pero ya no se componía con la misma intensidad, ni con el mismo espíritu, a pesar de que su estilo se mantuviera hasta mediados del siglo XIV, conviviendo con los inicios triunfales del Humanismo.

Sobre su colisión con la jerarquía eclesiástica y, en general, con la Iglesia, conviene hacer ciertas precisiones por haberse vertido contra los goliardos algunas acusaciones infundadas. Entre ellas destaca el paganismo atribuido a estos «clerici vagantes». Se trata de un mito. Su pensamiento era perfectamente católico, como ya destacó en su día R. García Villoslada ${ }^{57}$. La Iglesia no condenó en ellos, porque no lo había, ni un hipotético paganismo, ni herejía alguna; lo que reprobó fue su forma de vida, como lo había hecho antes ya, y lo volvería a hacer, con otros clérigos, no goliardos, pero que se comportaban indignamente en relación a su orden estamental, a pesar de seguir disfrutando del «privilegium fori». Valgan como ejemplo las disposiciones condenatorias de algunos sínodos de la Antigüedad, como los de Laodicea (360), Cartago (436), o Agde (506), sobre los clérigos que acudían a determinados espectáculos o se comportaban como ioculatores, con verbo indecoroso ${ }^{58}$. En el mismo sentido se pronunciaron los concilios ecuménicos de la plena y baja Edad Media. Así, en el IV concilio de Letrán de 1215 se dedicaron varios cánones a los clérigos incontinentes, ordenándoles evitar el pecado de sensualidad y abstenerse de los excesos del vino:

«Si no abusan del vino, el vino no abusará de ellos; que nadie se deje inducir a beber, puesto que la embriaguez hace perder el espíritu y enciende las pasiones carnales» $\gg$.

Fue en el concilio provincial de Tréveris de 1227 donde ya se habló abiertamente de los goliardos, dictaminando contra su forma de vida:

«Item praecipimus ut omnes sacerdotes non permittant trutannos et alios vagos scholares aut goliardos cantare versus super Sanctus et Agnus Dei aut alias in missis vel in divinis officiis» 60 .

\footnotetext{
57 «Su moral no era a veces conforme a la ética cristiana, lo cual no les impedía satirizar y fustigar cruelmente los vicios de los eclesiásticos. Sus versos pueden sugerir la idea de un poeta hedonista o naturalista, pero aquel naturalismo no era el de los que niegan toda norma o principio sobrenatural, sino el naturalismo práctico del hombre pecador, que en la juventud deja momentáneamente a un lado sus creencias para dar rienda suelta a sus instintos y pasiones, mas luego se arrepiente y hace penitencia. No se diga, pues, que vuelven al paganismo antiguo. Permanecen auténticamente medievales, con sincera fe en Cristo y con profunda adhesión a las enseñanzas de la Iglesia», Ob. Cit. pág. 296.

58 Cf. J. D. MANSI, Sacrorum conciliorum nova et amplissima collection, Florencia, 1750-1789, II, pág. 582, III, pág. 956, VIII, pág. 336.

59 Cf. R. FOREVILLE, Lateranense IV, Vitoria, 1974, pág. 171.

60 Cf. J. D. MANSI, Ob. Cit., XXIII, pág. 33.
} 
En el concilio de Rouen de 1231 se condenó a los clérigos de «la familia de Golías» a perder su privilegio eclesiástico, rapándoles el pelo para hacer desaparecer la tonsura. Una sentencia que se siguió en concilios posteriores como el de Château Gonthier (1231) o el de Sens (1339)61. En el sínodo de Maguncia de 1261 se dispuso la prohibición de alojar a los clérigos vagabundos, denominados popularmente «eberardinos»; en el de Lieja de 1287 se vedó a los clérigos desempeñar ciertos oficios considerados indignos, como carniceros, taberneros, juglares y goliardos; en el de Cahors 1289 se sentenció conjuntamente contra goliardos, juglares y bufones ${ }^{62}$. En las actas del concilio de Salzburgo de 1291 no se menciona el término goliardo, pero sí se habla de la «secta vagorum scholarium», realizando sobre ella la descripción más dura que las autoridades eclesiásticas habían hecho hasta el momento: son blasfemos, maldicientes, se exhiben desnudos en público, frecuentan las tabernas y a las meretrices ${ }^{63}$. Y, ya entrada la época moderna, el concilio provincial de Florencia de 1517 volvería a condenarles, metiendo en un mismo saco a los clérigos que hicieran de bufones o histriones, a los goliardos y a los juglares ${ }^{64}$. Pero la mala prensa de los goliardos no se detuvo en las disposiciones conciliares, sino que, de igual manera que en tiempos pasados San Benito o San Isidoro habían denunciado la existencia de esos clérigos o monjes vagabundos que dañaban la realidad eclesiástica, en la Baja Edad Media también hubo intelectuales que arremetieron contra «toda la farándula de los juglares» y, en concreto, contra los goliardos, como el canonista Enrique de Susa, el «Hostiensis» ( $¿-1271)$, en su obra De sententia excommunicationis, o Juan de Salisbury en su famoso Policraticus ${ }^{65}$. La insistencia de algunos obispos e intelectuales sobre la necesidad de condenar a goliardos y juglares llevaron a Bonifacio VIII a efectuar una condena de carácter ecuménico en 1298 en el Liber Sextus ${ }^{66}$, añadido a los cinco libros de las Decretales de Gregorio IX.

Todavía, sin embargo, se encontrarían con posterioridad algunas noticias sobre los goliardos, sobre su mala vida. Quizá, la más elocuente de todas sea la recogida en las actas del sínodo de Colonia de 1300, en donde se hace alusión a las malas artes empleadas por los goliardos para conseguir dinero, hasta el extremo de haber llegado a usurpar el oficio y la personalidad de cuestores y predicadores de indulgencias:

«Sacerdotes non permittant quaestionarios Goliardos vel quoscumque alios ignotos, intra parochiam suam in ecclesia, vel in via, vel in platea, vel in quibuscumque locis parochiae suae praedicare, vel ostiatim deferre indulgentias pro quaestu faciendo" ${ }^{67}$.

\footnotetext{
61 Ibidem. XXIII, págs. 215, 237 y 512.

62 Ibidem. XXIV, págs. 311, 910 y 1014.

63 Ibidem. XXIV, pág. 1077.

64 Ibidem. XXXV, pág. 223.

65 JUAN DE SALISBURY, Policraticus, I, cap. 8, donde realiza una fuerte censura general a cómicos, bufones y charlatanes. Edición preparada por M. A. LADERO QUESADA, Madrid, 1983.

${ }^{66}$ Corpus luris Canonici, ed. de E. FRIEDBERG, Graz, 1952, vol. II, pág. 1919. Cf. R. GARCÍA VILLOSLADA, Ob. Cit. pág. 301.

67 Cf. J. D. MANSI, Ob. Cit. XXV, págs. 21-22.
} 
Pero ¿hasta qué punto podemos asegurar que estos delitos concretos y graves estuvieron protagonizados por auténticos goliardos? Lo cierto es que se seguirían haciendo nuevas denuncias, aunque de lo que se iba a hablar ya era de «malfechores de corona» o de clérigos vividores y vagabundos, no de goliardos. La legislación, no obstante, desde el siglo XIV, se volvería más insistente que nunca sobre este asunto. Era necesario que los clérigos fueran dignos, y así mostrarse ante los laicos. La «buena fama» del eclesiástico pasó a considerarse pilar fundamental del gran edificio de la Iglesia. Había que ser decente y respetable y, además, demostrarlo y parecerlo. Por ello se prodigarían las disposiciones en multitud de sínodos sobre la necesidad de que los clérigos dieran una imagen ejemplar a los laicos y fueran, en definitiva, el espejo donde mirarse ${ }^{68}$. Esta preocupación por su buena imagen pasó también a la legislación civil. Así, por ejemplo, Alfonso X el Sabio dedicó varias leyes a las actividades lúdicas y oficios prohibidos al clero, tales como: hacer juegos de escarnio, andar con mujeres "sospechosas", entrar en monasterios femeninos, torear...69.

Pero no fueron sólo la jerarquía eclesiástica y algunos poderes civiles los que reprendieron y condenaron a los goliardos por su forma de vida y su crítica contundente a los prelados y, en general, al orden social establecido. Existió, según ya apuntamos, un tercer factor que contribuyó decididamente a la desaparición de este movimiento. Se trata de la nueva cultura emergente, del Humanismo, que se volvió con desprecio hacia la poesía goliárdica por considerarla vulgar y carente de erudición. Para los humanistas la poesía latina debía aspirar a imitar lo mejor posible la forma métrica de Virgilio, Horacio o Marcial. Para ellos, utilizar el latín en el verso rítmico, silábico y acentual, carecía de sentido, debiendo quedar relegado para los poetas en lengua vernácula. El Humanismo se iba imponiendo progresivamente y, en los dos últimos siglos del Medievo, quien deseara versificar en latín debía hacerlo, para ser reconocido como buen poeta, en la forma clásica arcaizante y en muchos casos imitadora- que los intelectuales italianos habían puesto de moda. Así, a los poetas que realmente pretendieran volcar su corazón en los versos que escribían no les quedó otro remedio que hacerlo en su lengua materna. Los versos goliárdicos dejaron de ser los del hombre culto, pero tampoco podían ser los versos del pueblo, porque las gentes sencillas no los entendían.

En la Baja Edad Media, no obstante, el verso latino rítmico y rimado siguió cultivándose por los llamados "goliardos a lo divino", ya mencionados, que en lugar de cantar a la taberna o hacer sátiras sociales, lo hicieron a Jesucristo y a los santos. Son himnógrafos que aprendieron la manera de versificar de los goliardos y

68 Sobre el tema de la «buena fama» del clero, véase: A. ARRANZ GUZMÁN, «El clero», en Orígenes de la monarquía hispánica: propaganda y legitimación (ca. 1400-1520), J. M. Nieto (dir.), Madrid, 1999, págs. 141-173.

69 Partidas, I, tit. VI, leyes 36, 37, 43, 47 y 49. Sobre este tema, véase: A. ARRANZ GUZMÁN, «Fiestas, juegos y diversiones prohibidos al clero en la Castilla bajomedieval», Cuadernos de Historia de España, Buenos Aires, LXXVIII, 2004, págs. 9-33. 
que heredaron algo de sus metáforas y estilo, como el arzobispo de Upsala Birger Gregersson (+1383), Boncore de Santa Vittoria, que compiló en Aviñón una colección de 129 himnos (1340), el obispo de Londres y cardenal Adam Easton (+1397), o el franciscano inglés Walter Wiburn (+1367) quien, en su ingenuidad, cantó a la Virgen María con expresiones empleadas por los goliardos en sus canciones eróticas ${ }^{70}$. Todo ello llevó, en poco tiempo, a que el goliardismo quedara reducido a las ocasionales composiciones burlescas y a las canciones frívolas que los estudiantes entonaban al son de algunos instrumentos. La famosa canción goliardesca "Gaudeamus igitur, iuvenes dum sumus/ Post iucundam iuventutem,/ post molestam senectutem,/ nos habebit humus...» recibió su forma actual del poeta Josef Victor Scheffel (1826-1886). También algún erudito, con deseos de probar fortuna en la poesía o, sencillamente, para divertirse, realizó en época contemporánea alguna composición al modo goliardesco no demasiado afortunada. Para España tenemos el caso de M. Menéndez Pelayo, quien nos dejó dos poemas, uno que comienza «In taberna ingrediamur/ scholares et goliardi...»; y otro sobre un estudiante en Salamanca: «Ave salmantina/ civitas gloriosa/ gloria litterarum/ semper speciosa. /Ecce tibi venit/ pauper scholaris,/ huius vitae et morum/ forte recordaris.... 71 .

Pero si el goliardismo como movimiento cultural había desaparecido ya al iniciarse la Baja Edad Media, fue también a partir de entonces cuando en la Corona de Castilla empezaron a dictarse numerosas disposiciones en un más que nutrido número de concilios y sínodos sobre la existencia de clérigos vagabundos y vividores, siempre acompañadas de consejos edificantes relacionados con la necesidad de ofrecer una buena imagen del estamento. Así, en el sínodo salmantino de 1451 su obispo se lamentaba de cómo los clérigos se habían acostumbrado a jugar a los dados y las tablas y a apostar dinero, algo siempre prohibido y urgente de erradicar:

«a los clérigos es conveniente honestidat e templança en muchas cosas, por que por olor de buena fama e exemplo los seglares reçiban dotrina» ${ }^{72}$.

Sin embargo, lo cierto es que los abusos de los clérigos fueron una constante en la sociedad medieval. Unos, por mantener barraganas; otros, por no cumplir, o hacerlo simoniacamente, con las obligaciones de su ministerio; otros, los más próximos al tema que nos ocupa, por llevar una vida errante, de vagabundos. En las Cortes castellanas, como luego veremos, los procuradores de las ciudades también denunciaron una y otra vez estas realidades. La alarma era tan grande que uno de los motivos fundamentales por el que los Reyes Católicos reunieron la asamblea o congregación de Sevilla de 1478 fue el de tratar la reforma del esta-

\footnotetext{
70 Sobre estos goliardos a lo divino, véase: R. GARCÍA VILLOSLADA, Ob. Cit. Págs. 286-289.

71 Ibidem. Pág. 304.

72 A. GARCÍA GARCÍA (dir.), Synodicon Hispanum, (=S. H.), 10 vols. Madrid, 1981-2011. Vol. IV, pág. 308.
} 
mento eclesiástico ${ }^{73}$. La situación había llegado a tal extremo, sobre todo en relación con los oficios que desempeñaban los clérigos, que los monarcas se vieron obligados a solicitar que se supiera por ley cierta quiénes eran clérigos verdaderos y quiénes no. Deseaban que de una vez por todas se determinase cuáles eran las condiciones por las que un clérigo podía beneficiarse de la inmunidad eclesiástica. En la reunión sevillana se concretaron las siguientes medidas: los tonsurados debían llevar la corona del tamaño de una «blanca vieja» y los vestidos reglamentados de los clérigos; la obligación de jurar ellos mismos, sus padres o sus tutores, que recibirían todas y cada una de las órdenes; la prohibición de vivir amancebados y de desempeñar profesiones incompatibles con la honestidad de su orden. Sin embargo, la existencia de estos «clérigos falsos», vividores, trasnochadores y bebedores se mantendría inalterable. Los Reyes Católicos no consiguieron demasiado. Sirvan como ejemplo las palabras vertidas por el obispo burgalés don Pascual de Ampudia en sus constituciones del año 1500, donde relató el hecho de que, visitando su obispado, le habían denunciado a algunos clérigos que

«pospuesto el temor de Dios, en mal exemplo de los que lo ven, frecuentan las tabernas e comen e beven e juegan en ellas, e otros se dan tanto al vino que se embriagan, de lo qual se han causado muchos males ${ }^{74}$.

La existencia de eclesiásticos de vida poco edificante, de «clérigos falsos», por denominarlos de acuerdo con una de las formas elegidas en nuestro Medievo, venía de muy atrás. Por ello, y siguiendo en buena medida las pautas marcadas por la Iglesia, el tema tuvo también su proyección en la legislación civil. Las leyes mencionadas que dedicó Alfonso X el Sabio en de las Siete Partidas son un buen ejemplo de la preocupación por parte de los poderes públicos ${ }^{75} \mathrm{y}$, más aún, las noticias que nos proporcionan los textos conservados de las asambleas parlamentarias. Concretamente, en las actas de Cortes castellanas, así como en la documentación generada durante su celebración, los asuntos que aparecen con mayor frecuencia, respecto a las relaciones mantenidas entre clérigos y laicos, son los que se pueden calificar de especialmente espinosos. Los cuadernos de peticiones de los procuradores de las ciudades reflejan el lado más oscuro de la clerecía, abarcando todos los peldaños de su estamento (abusos en los abadengos, excesos perpetrados con la excomunión, barraganas e hijos bastardos, problemas con los excusados o paniaguados...) En definitiva, en los cuadernos de los procuradores, no se reflejan las posibles virtudes del clero, ni la precaria economía que sufrían algunos de sus miembros, ni sus bondades como pastores - algo comprensible, por otra parte, dado el carácter de la institución a la que se dirigían y el

73 Sus actas fueron publicadas por F. FITA, «Concilio nacional de Sevilla (8 de julio-1 de agosto 1478)", Boletín de la Real Academia de la Historia, 1893, págs. 212-257.

74 S. H., VII, pág. 203. Sobre la preocupación de determinados prelados por la existencia de tales realidades en sus respectivas diócesis, véase: A. ARRANZ GUZMÁN, «Las visitas pastorales en la Corona de Castilla durante la Baja Edad Media. Un primer inventario de obispos visitadores», En la España Medieval, Universidad Complutense, 2003, págs. 295-339.

75 Véase nota 70. 
propósito último de los mismos - sólo aquellos aspectos que ocasionaban algún perjuicio a los laicos, ofreciéndose una imagen desoladora, en especial del grupo inferior y más débil de la clerecía ${ }^{76}$.

Los propios monarcas castellanos, aunque con mucha menor frecuencia que los procuradores, también aludieron en alguna ocasión en las asambleas del Reino al malhechor eclesiástico, que perpetraba «malfetrías». El primer ejemplo de interés se encuentra en las palabras pronunciadas por Alfonso XI en las Cortes de Valladolid de 1325, tras oír las denuncias de los oficiales regios:

«...sepan los prelados que mios offiçiales que se me querellan que algunos clerigos que fazen muchas malfetrias, e digoles que manden fazer escarmiento e justicia en aquellos quelo fizieren, et sinon que me tornare aellos por ello» ${ }^{77}$.

Pero si bien es cierto que las protestas ciudadanas contra cualquier exceso del clero salpican las actas de casi todas las Cortes, también lo es que las denuncias concretas en torno a los vicios del escalafón más bajo del estamento aparecen en ellas sólo a partir de los últimos años del reinado de Alfonso $\mathrm{XI}^{78}$. Las protestas de los representantes de las ciudades se intensificaron desde las primeras Cortes celebradas por Pedro I, en Valladolid el año 1351, cuando definitivamente estos clérigos pasaron a ser calificados de «trasnochadores, tabernarios y falsos» ${ }^{79}$.

El panorama presentado en las actas de reuniones posteriores invita a deducir la existencia de una especie de subgrupo estamental cada vez más amplio. Prueba de ello es el incremento de protestas y denuncias llevadas a cabo por parte de los procuradores castellanos entre los reinados de Enrique II y Juan II, en concreto, en las Cortes de Burgos (1379), Soria (1380), Briviesca (1387), Palencia (1388), Tordesillas (1404), Palenzuela (1425), Zamora (1432), Madrid (1433 y 1435) y Valladolid (1442) ${ }^{80}$. En estas Cortes se acusó a ciertos clérigos de: excusarse de los pechos y tributos a los que estaban obligados; de «traer coronas non aviendo órdenes»; de casarse «encobiertamente»; de ser vagabundos, holgazanes, y «rufianes e malfechores de corona», en clara alusión a la tonsura, «peleadores e pendencieros». Contra ellos, muchas veces ladrones también y gentes sin vocación - continuaban lamentándose los procuradores - los justicias reales se encontraban imposibilitados a la hora de intentar imponer medidas legales, al ser amenazados en seguida con la excomunión por parte de estos personajes ${ }^{81}$. Ante tal si-

76 Cf. A. ARRANZ GUZMÁN, «Clérigos y laicos en las Cortes castellano-leonesas: la conflictividad como hilo conductor», en El Reino de León en la Alta Edad Media, IX, León, 1997, págs. 637-717.

77 Cortes de los antiguos reinos de León y de Castilla (=Cortes), Madrid, 1861, vol. I, pág. 396.

78 Cortes, I, pág.630.

79 Ibidem. II, pág. 21.

80 Ibidem. II, págs. 291, 303, 369, 539 y 543; III, 172 y 408.

81 Sobre la excomunión en el Medievo y las irregularidades y denuncias que generó su aplicación, véase: A. ARRANZ GUZMÁN, «Excomunión eclesiástica y protesta ciudadana», en El conflicto en escenas. La pugna política como representación en la Castilla bajomedieval, J. M. Nieto (dir.), Madrid, 2010, págs. 247-278. 
tuación, los procuradores solicitarían, una y otra vez, al monarca de turno que dichos «malfechores de corona» fueran ajusticiados, pero por justicias civiles no eclesiásticas, y que se suplicara al Papa «para que ninguno de los tales malfechores non goze nin pueda gozar de privilegio eclesiástico, salvo los que fueren dados e dispuestos en ofiçio a servicio de la iglesia o fueren beneficiados» ${ }^{82}$. En esta última queja y petición, formulada en las Cortes de Olmedo de 1445, se aludía a una lamentable realidad que se iba extendiendo al igual que una mancha de aceite, como era el hecho de que muchos de estos clérigos vagabundos carecían de beneficio eclesiástico del que poder mantenerse.

La situación del conjunto de la clerecía se había deteriorado considerablemente a fines del Medievo, a pesar de los impulsos dados en sentido contrario por un buen número de obispos reformadores dentro y fuera de nuestras fronteras. En cualquier caso, la existencia de los llamados «clérigos falsos» o vagabundos en estas últimas centurias no puede ligarse ya con una hipotética continuidad cultural del movimiento goliárdico, puesto que había desaparecido hacía mucho tiempo ya, sino con otros motivos de muy distinta índole, tales como la búsqueda por parte de algunos tonsurados de un medio de vida, considerado cómodo y saneado, o la puntual relajación moral en las filas del clero o, finalmente, la escasez y deficiente distribución de los beneficios eclesiásticos.

En relación con el primer motivo subrayado, no hay que olvidar que el tonsurado, para disfrutar de los privilegios propios del estamento eclesiástico, debía comprometerse a seguir el escalafón, sin negarse a recibir las sucesivas órdenes, menores y sagradas. Una obligación que los sucesivos pontífices y las autoridades diocesanas recordaron una y otra vez en multitud de concilios y sínodos desde el IV de Letrán de 1215, del mismo modo que la vida decorosa de la que debían hacer gala para ser ejemplo de los fieles. Sin embargo, el día a día resultaría mucho más complejo. Así, sin abandonar jamás e, incluso, respaldándose en los favores y gracias que les reportaba su condición clerical, algunos eclesiásticos nunca estuvieron dispuestos a cumplir con sus obligaciones y, mucho menos, con el decoro al que su condición obligaba ${ }^{83}$. Pero ¿cómo obligar a los simples tonsurados o curas de almas a cumplir con sus deberes y a comportarse de acuerdo con su posición social cuando las propias autoridades eclesiásticas no siempre lo hacían? Las noticias sobre el mal comportamiento o el escaso celo de algunos prelados son abundantes, así que valga como pequeña muestra la queja elevada por el arzobispo don

82 Cortes, III, pág. 192.

${ }^{83}$ Tampoco el clero regular escapó a las acusaciones sobre algunas de sus actuaciones y formas poco decorosas. Sirvan como ejemplo, en primer lugar, la carta enviada en 1281 por la priora de Santa María de Zamora al cardenal Ordoño de Tusculum, donde le relataba los estragos que un grupo de sus monjas perpetraban con religiosos dominicos, quienes pernoctaban con las más jóvenes «holgando con ellas muy desulutamientre», Cf. P. LINEHAN, La Iglesia española y el Papado en el siglo XIII, Salamanca, 1975; y, en segundo, las disposiciones realizadas en el concilio ovetense de 1115 y en el de Lérida de 1173 sobre la existencia de monjas y monjes incontinentes y desertores, que se repetirían en numerosas ocasiones con posterioridad a esta fecha, Cf. J. TEJADA Y RAMIRO, Colección de cánones y de todos los concilios de la Iglesia española, Madrid, 1851, vol. III, págs. 240 y 279. 
Juan de Aragón en el concilio provincial que celebró en Toledo el año 1324 sobre la «negligencia de aquellos obispos que se niegan a asistir a sínodo cuando se les llama», sin haber demostrado impedimento legítimo alguno, por lo que implica de desprecio a la autoridad y por ser causa de males posteriores en lo que a corrección de costumbres y excesos se refiere ${ }^{84}$. Por todo ello no es de extrañar la cantidad de referencias que aparecen en las actas sinodales de la época sobre el absentismo constatado de un nada despreciable número de beneficiados. Una de las más interesantes por sus contenido, ya que hace alusión a una forma de actuar especialmente relacionada con el sentir y el comportamiento mantenido siglos atrás por los goliardos beneficiados y, en general, por todos los miembros de la «familia de Golias», es la denuncia que realizó el obispo burgalés don Pascual de Ampudia en el sínodo que celebró en 1498 en torno a los abandonos injustificables por parte de los eclesiásticos con cura de almas. No deja de ser curioso cómo este prelado que, de acuerdo con el movimiento reformista impulsado por la Iglesia, había valorado la realización de estudios superiores a la hora de favorecer de manera especial a los clérigos-escolares de su diócesis, a través de una constitución, se encontró con la triste realidad de que algunos de los clérigos más favorecidos, una vez lograda sus metas beneficial e intelectual, parecían haberse olvidado del fin último para el que habían sido elegidos, no cumpliendo con sus obligaciones:

«Por una nuestra constitución hovimos ordenado e mandado que los graduados en theologia e canones se hayan de preferir, en ciertos casos cerca de las provisiones de los beneficios patrimoniales, a los no graduados, por que en la yglesias hoviese letrados que las decorasen e mejor gobernasen e serviesen. $E$ havemos fallado que el fin para que fezimos la dicha constitution no se consigue, porque muchos de los tales graduados, despues que son proveydos de los tales beneficios, no residen en ellos, según fue nuestra intención en la dicha constitution, antes, luego que son proveídos, se absentan e se van a los estudios o a otras partes donde les plaze, de manera que las yglesias quedan defraudadas en el servicio ${ }^{85}$.

Por supuesto que los clérigos a quienes se denuncia en el texto no eran goliardos, sino personas que habían entrado en la carrera eclesiástica, bien por conseguir alcanzar sus aspiraciones intelectuales, que de no haber sido a través de la condición de clérigos-escolares no hubieran logrado, bien, sencillamente, por hacerse con una renta beneficial de la que poder vivir, pero sin tener en consideración las obligaciones que conllevaba su titularidad. Lo cierto es que estos clérigos cultos ya no versificaban, sino que sólo iban «donde les plaze» y, en el mejor de los casos «a los estudios». La pena a la que se enfrentaban no era pequeña: la privación de su beneficio. Pero las tres amonestaciones previas que debían recibir para que se llevara a efecto, así como el hecho de no iniciarlas hasta pasados ocho meses, y las continuas amenazas pronunciadas en diferentes diócesis por

84 J. TEJADA Y RAMIRO, Ob. Cit. pág. 522.

85 S. H. VII, pág. 270. El absentismo de algunos clérigos alcanzó tales límites que llegó a ser tratado en las Cortes de Castilla por parte de los representantes de las ciudades, de manera especial en las celebradas en Valladolid el año1295, Cf. Cortes, II, pág. 456. 
parte de sus respectivos obispos, en el mismo sentido y en tiempos muy lejanos ${ }^{86}$, indican el escaso, incluso, el nulo efecto que tuvieron.

El segundo motivo mencionado, la escasez de beneficios, llevó a que en los concilios y sínodos se insistiera, una y otra vez, para que no se ordenara a más clérigos si se carecía de los suficientes beneficios con que dotarles. Pero tanto la subdivisión de dichos beneficios, como la posesión de varios en unas solas manos, eran males antiguos y gemelos; y sólo con la eliminación del primero se podría erradicar el segundo. Por ello, ya a mediados del siglo XIII, el legado apostólico Juan de Abbeville en su visita a Castilla había invocado la constitución de Alejandro III mediante la que se obligaba a los obispos a mantener por su cuenta a los clérigos que se ordenaran sin título beneficial. Y en el concilio de Lérida de 1228 se denunció también la existencia de beneficios excesivamente pequeños para sustentar a un sacerdote. La situación, en cualquier caso, resultaba de difícil solución. Paralelamente, el legado recordó las disposiciones reformistas del IV concilio lateranense en el concilio vallisoletano de este mismo año sobre la forma de vida y honestidad de los clérigos ${ }^{87}$. Dichas disposiciones fueron repetidas en casi todos los sínodos diocesanos y subrayadas por los obispos en sus visitas pastorales durante los dos últimos siglos medievales, pero sin alcanzar el éxito deseado por parte de las autoridades eclesiásticas ${ }^{88}$.

Pero los problemas relacionados con la provisión de beneficios eclesiásticos menores, así como las posibles dudas vocacionales de algunos clérigos eran cuestiones que no concernían a los procuradores de las ciudades en Cortes. Lo que sí les importaba eran todos aquellos asuntos que de alguna manera podían repercutir negativamente en su vida cotidiana y que, en muchos casos, tenían como protagonistas a esos «malfechores de corona», «clérigos vagabundos» o clérigos falsos», como lo demuestran las quejas elevadas en las Cortes antes mencionadas sobre los clérigos «peleadores», jugadores y trasnochadores. Los sucesivos monarcas dieron contestación a todas ellas. En unas ocasiones las respuestas presentadas eran las que deseaban oír los ciudadanos; en otras, se limitaban a remitir el problema a los prelados del Reino, al cardenal de turno, o al mismo Papa. En cualquier caso, estos clérigos pendencieros, errabundos, desertores, malhechores o falsos ya no eran goliardos.

86 Sínodo de Avila de 1348, de Coria de 1457, de Badajoz de 1501, Cf. S. H. págs. 24, 146 y 36 ; y de Burgos de 1374, Palencia de 1345 y 1500, Cf. S. H. VII, págs. 206, 371 y 466.

87 «Stablecemos que todos los clérigos diligentes se guarden muy bien de gargantez et de bebedez, et que non usen de los oficios desonestos, de los quales usan algunos legos. Item establecemos que los clérigos non sean en compañas do están joglares et trasnochadores, et que escusen de entrar en las tabiernas, salvo con necesidat, et con priesa, et non joguen los dados, nin las taulas...». Cf. J. TEJADA Y RAMIRO, Ob. Cit., pág. 326.

${ }^{8}$ Cf. A. ARRANZ GUZMÁN, «Las visitas pastorales a las parroquias de la Corona de Castilla durante la Baja Edad Media», En la España Medieval, 2003, págs. 295-339. Desde la década de los 70 del pasado siglo se han multiplicado los estudios sobre clero parroquial, por lo que me remito a la bibliografía recogida en este artículo y a la que aparece en los citados de las notas 69, 76 y 81. 


\section{CONCLUSIONES}

La conducta errante y disoluta de algunos eclesiásticos constituyó una de las realidades más censuradas desde los primeros siglos de la Iglesia ${ }^{89}$. Lo que ocurrió en la plenitud medieval es que tal realidad coincidió con otra, de características externas similares, como fue la de los goliardos, unos clérigos-escolares de similar conducta relajada e incómoda para el resto de los mortales, pero también verdaderos intelectuales que supieron dar un aire nuevo a la poesía en latín y que, como tales, desaparecieron a mediados del siglo XIII. Después quedó de nuevo, únicamente, como antaño, el clérigo vividor, calificado, en unas ocasiones, de «falso" $y$, en otras, de «malfechor de corona», que tan sólo coincidía con los genuinos goliardos en su pasión por el juego, el vino, las mujeres y el escándalo, en general. La existencia de este subgrupo merecería un análisis específico, a pesar de la dificultad que entraña el llegar a conocer, desde el punto de vista cuantitativo, lo que supusieron, así como las causas que en mayor o menor medida lo originaron, aunque las hayamos intuido en las páginas anteriores. Todo parece indicar que unos decidieron tonsurarse por los provechos y favores que conllevaba el «privilegium fori», sin reparar en sus obligaciones; y que otros, incluso ya ordenados, no tuvieron más remedio que lanzarse a los caminos por carecer de beneficio eclesiástico suficiente del que mantenerse. La falta de vocación, unas veces, y su exigua moralidad, otras, se encargaron del resto. Tampoco hay que olvidar el contexto en el que el fenómeno de estos clérigos se desarrolló; el de una época en la que el umbral de la pobreza era traspasado con facilidad por amplios sectores de la población. El mundo de los pobres y de los marginados creció. Fueron tiempos de pestes, de malas cosechas y de guerras. $Y$ en este tipo de sociedad, el genuinamente pobre, el enfermo, el vagabundo y el truhán fueron contemplados de forma simi$\operatorname{lar}^{90}$. El incremento de estos marginados conllevó que la percepción social sobre los mismos cambiara respecto a la mantenida en el período altomedieval, cuando se recomendaba a todo buen cristiano recibir al pobre que llamara a su puerta como si se tratara de Jesucristo. En el ocaso del Medievo, en cambio, los sentimientos de desprecio, odio o temor hacia todo tipo de marginados fueron los predominantes. Pobres y vagabundos acabaron por identificarse, y éstos con los juglares y los judíos, formando la «familia del diablo», como la había definido ya en el siglo XIII el franciscano Bertoldo de Regensburg. Poco importaba que el vagabundo, el truhán, o el malhechor, fuera laico, clérigo, o falso clérigo, para que sus

${ }^{89}$ Las alusiones realizadas en el IV concilio de Toledo del año 633, por recordar sólo un ejemplo, así lo demuestran, del mismo modo que la temprana preocupación que ocasionaron a las autoridades eclesiásticas este tipo de clérigos. Cf. J. VIVES, Concilios visigóticos e hispanorromanos, BarcelonaMadrid, 1963.

90 Sobre la evolución del concepto de pobreza, así como sobre la cambiante percepción que se generó en la sociedad durante los últimos siglos del Medievo en torno a la figura del pobre resultan especialmente interesantes los trabajos de M. MOLLAT, en concreto: «La sensibilité médiévale au temps de crises (s. XIV-XV)», en Actes du 102 congrés national de sociétés savantes, Limoges, 1977, págs. 13-30, y Les pauvres au Moyen Age, París, 1978, págs. 44-46 y 93-104. 
«malfetrías», y su escandaloso comportamiento fueran denunciados por los ciudadanos. Pero los goliardos, también marginales, pendencieros, desvergonzados y tumultuosos, ya no pertenecían a esta época. Su amor por el verso en latín y por el mundo de la cultura, en general, se había desvanecido. De ellos sólo quedaba ya el reflejo de su piel festiva. 
